\title{
Reproductive Life in Nineteenth Century Sweden: An Evolutionary Perspective on Demographic Phenomena
}

\author{
Bobbi S. Low
}

School of Natural Resources and Evolution and Human Behavior

Program, University of Michigan, Ann Arbor, Michigan

\section{INTRODUCTION}

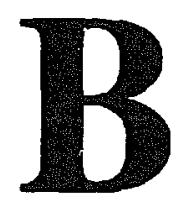

iologists, as well as demographers and anthropologists, are interested in lifetime reproductive patterns, in sex differences, and in ecological correlates of behavior. The questions asked are likely to diverge somewhat, because the underlying paradigms differ significantly. Demographers tend to focus on population performance, biologists on variance in individual reproductive performance. For example, the classic demographic transition model gives central importance to correlations in fertility and mortality; the question is whether fertility decline occurs in the context of mortality decline/survivorship increase (e.g., Knodel 1986, Livi-Bacci 1986). Livi-Bacci (1986) and others have found that fertility declines are typically led by households of prominent or high-status individuals. Lesthaeghe and Wilson (1986) proposed that economic factors influence fertility shifts. Although they restricted their argument to considerations of mode of production (i.e., labor-intensive farm production), their argument may be extended to the question of resource level and type. Evolutionary approaches converge on these questions and raise other questions not widely seen as relevant to demographic approaches; several relatively common patterns are not predicted by any current demographic theory, but are predicted by theory in evolutionary and behavioral ecology.

In most demographic approaches (for exceptions, see e.g., Voland 1990, review by Borgerhoff Mulder 1991), specific proximate correlations, such as the role of age at marriage, age at last birth, and interbirth interval as

Received May 11, 1990; revised July ?, 1991.

Address reprint requests to: Bobbi S. Low, Ph.D., School of Natural Resources and Evolution and Human Behavior Program, University of Michigan, Anı Arbor, MI 48109. 
they affect fertility, are explored. "Why" questions of ultimate function (Willians 1966; i.e., impact on relative reproductive success) are not raised, or are deferred. "Why" questions have two principal forms in biology: proximate triggers or correlates (e.g., age at marriage, common in demographic approaches) and ultimate selective causes (impact on lineage persistence). These two approaches are not alternatives, but complementary. Most demographic approaches to causal analysis involve what evolutionary biologists would call proximate triggers. To paraphrase Bateson (1982), we cculd take a piece of machinery, animate or inanimate, and learn an enormous amount about exactly how it was assembled, and still not understand what it was for, or how the design had evolved. Similarly, we can, as do most demographic studies, examine the particulars of reproductive performance (e.g., starting, stopping, spacing, how trends spread) without ever asking whether the particular behaviors or trends, in specific environments, are advantageous or disadvantageous for their bearers, in terms of net lifetime reproductive success and lineage persistence. Here, I want to focus on the less studied sec. $\cdots$ d question.

Using this framework I examine several phenomena, including sex differences in resource contrel and reproduction, sex ratio and mother's age, and influences on inter-birtin iniervals. These represent questions for which demographic and evolutionary theory offer different levels of explanation, or for which demographic theory, concerned as it is with population patterns, has no guidance, but for which predictions arise out of the evolutionary and behavioral ecological paradigm. This paper analyzes the reproductive patterns of a sample of mid-19th century Swedish men and women living in seven parishes, addressing survivorship, marriage, remarriage, marital vếsus nonmarital fertility, survivorship of children, and age effects as these varied for people of different status, living in different parishes.

\section{BEHAVIORAL ECOLOGY AND HUMAN RESOURCE USE}

A behavioral ecological approach makes several predictions about fertility, mortaiity, male-female differences in lifetime reproductive patterns, and about how these are predicted to differ in various environments. The return curve for reproductive success gained per unit of resources or status acquired differs for mating and parental effort (e.g., Low 1978, 1990a). Mating effort, typical of mammalian males, has a large fixed cost; then the curve may rise steeply; additional matings cost re! tatiely little. For example, a red deer male, even to try for a first mating, must grow large (involving a cost of delayed maturation), grow antlers, and fight for dominance and control of good feeding grounds. The initial cost is great; the cost associated with each individual mating is small. For mammalian mothers, each offspring costs approximately as much parental effort as any other, and the maximum possible number of offspring is likely to be lower than for males. 
In mammals, including many human populations, males, whiie having the same average number of offspring as females, experience more variance in reproductive performance. Resources, status, and power co-vary with reproductive success $f \wedge r$ males; for females, survivorship (number of reproductive years) is most important (e.g., Clutton-Brock et al. 1982, Le Boeuf and Reiter 1988). Because male variance is high, great expenditure and risk-taking may be profitable (e.g., Low 1988; 1989a, b; 1990a, b, c). Men in most societies for which there is information use resources to gain reproductively. In many societies, men's increase in reproductive success is accomplished through polygyny-additional wives. In 10 of 12 societies reviewed by Hill (1984), resource control enhanced reproductive success. In some societies the relationship is quite straightforward: in the Turkmen, Irons $(1979 \mathrm{a}, \mathrm{b})$ found that richer men had more wives and more children than poorer men. Borgerhoff Mulder $(1988,1990)$ found that in the African Kipsigis, richer men married younger wives (of higher reproductive value, Fisher 1958) and produced more children than poorer men, although with the introduction of western technology and medicine, differentials were reduced. In many traditional societies (Betzig 1986), there are formal reproductive rewards associated with status: high-ranking men have the right to more wives, and hai e significantly more children than others. Even in societies such as the Yanomamö, in which few physical resources are owned, achieved status (Chagnon 1988) and male kin available for coalitions represent a resource, so that men manipulate kinship terms in ways that make more women available for mates and powerful men as partners (Chagnon 1982), so that reproductive success is uneven. In the Ache, too, good hunters have more children than other men (Hill and Kaplan 1988a, b). Wealth correlates with reproductive success on Ifaluk (Turke and Betzig 1985). Even in "monogamous" societies, monogamy may be far from absolute. In the Kalahari Bushmen, living in a resource-limited environment, five percent of the men, the best hunters, still manage to have two wives (Lee 1979). In other monogamous societies, such as the one considered here, I will argue that men of high status or great resources manage to accomplish the same ends through marrying younger women and remarrying more often than others.

Current Western technological societies show more ambiguous data: Daly and Wilson (1983) found that fertility correlated with men's income in 1970 census data. Further, there is some evidence that men in industrial "monogamous" societies remarry more than do women, with resulting increased variance in men's reproduction-effective polygyny (Essock-Vitale 1984). On the other hand, Vining (1986), using proy y measures such as educition (rather than income) argued that there was a negative correlation between wealth and fertility. It is of some interest, therefore, to explore ecological patterns of fertility during the demographic transition, to see if the resource-reproduction correlations seen in traditional societies disappear. 


\section{Recources and Reproduction in Nineteenth Century Sweden}

The behavioral ecology of reproduction in other mammals, and in pre-industrial societies, lead to some general predictions about sexual dimorphism in resources and reproductive patterns in a society such as nineteenth century Sweden. If resource control varies among men (e.g., with occupation or land ownership), and reproductive value (Fisher 1958) varies among women (with age), then nonrandom patterns of marriage and fertility are likely to result.

Nineteenth century Sweden was large!y agricultural, with emerging protoindusirialization (Mendels 1981): geographically scattered market activity which involved transforming raw materials into "made" commodities, but with a large part of the labor force working part-time or at home. The family could function as a form of economic enterprise (see also Flandrin 1979, Habbakkuk 1955). Such protoindustrialization tended to develop in regions combining an underemployed, land-poor population, with access to urban markets (e.g., Tilly 1978). In Sweden, protoindustrialization was probably related $: 0$ land enclosure and inheritance changes usuring the nineteenth century (Jörberg 1975). The economic changes have been characterized as drastic (Jörberg 1975). At the beginning of the nineteenth century, more than $80 \%$ of Sweden's population was employed in agriculture (Jörberg 1975), and agricultural production was barely enough to support the population; until 1830, Sweden depended largely on imported grain.

By 1800 , Sweden had a population of 2.3 million; from 1800-1830 the population had increaseci by $23 \%$, and fiom $183 \mathrm{C}-1860$ by $34 \%$ to a total of 3.9 million (Jörberg 1975). Land reform, economic development, and rapid population growth combined to create great changes in people's lives. These changes were far from uniform, however. Population growth was greatest in southern and western Sweden and in Norrland, and lowest in eastern and central areas. Since the economic bases differed geographically also, and growth in those economic bases varied, it is not surprising that people's reproductive lives might differ, and that changes in reproductive life might differ geographically also. Low (1989b, 1990b) and Low and Clarke (1991a, b) have examined some aspects of this variation for men.

In Sweden, marriage followed the "European" pattern, with women marrying for the first time in their early- to mid-twenties, and rren in their late twenties. Age-specific fertility was not closely linked to marriage age (Low and Clarke 1991a). At marriage the new couple typically set up their own independent household; a relatively high proportion of individuals never married (Low 1989b, 1990b). From 1686 to approximately 1810, the nobility practiced "fideicommiss," or male primogeniture, with the constraint that the eldest son must continue the practice (Malmström 1981, Inger 1980). Until 1845 , sons inherited twice as much as cuaughters in cases of intestancy; later, daughters had equal inheritance rights, although sons had first choice of the land and goods which were to be their inheritance, and sons could 
purchase their sisters' inheritance from them (Lo-Johansson 1981, Ingar 1980). This meant that disputes occasionally arose over the value of the exchanged inheritance items; purchasing needed land from a sibling could prove economically onerous, but also siblings sometimes complained that they did not receive fair value (not uncommon elsewhere in Exirope; see Habakkuk 1955).

Even after the shift from fideicommiss, and even after legally equal inheritance rules for both sons and daughters, inheritance was often biased by birth order (see Gaunt 1987, Low 1989b, 1990b), and a bias favoring the first son was perhaps more evident in the no thern areas. Legal agreements in which a father ceded his land to one (usually the eldest) of his sons before his death, typically in return for room, food, and certain other rights, were common. But as Gaunt (1987) notes, during the nineteenth century the payments delivered to the retiring father increased in size, and receiving a farm became an economic burden (see also Smith 1973). Indeed, default was common (Gaunt 1977), and Gaunt (1983) cites contemporary jokes about arsenic as "retirement medicine." Thus, some tension probably existed both within and between generations over resources.

Even such a brief overview suggests that in several important ways resources might well affect reproductive patterns differently for men and for women in this society, as in so many others.

\section{Predictions From the Behavioral Ecological Hypothesis}

1. Fisher's (1958) concept of reproductive value was used by Keyfitz (1985: 142-161) to make predictions about migration, contraception, and population growth; it is also useful in understanding trends in marriage age and remarriage rates. Reproductive value, derived from age-specific fertility and mortality rates, is defined as the probable number of daughters a female will have in the rest of her life. It thus encompasses age-specific fertility and survivorship functions. Although reproduction was overwhelmingly within marriage in this sample, women's ages at marriage and age-specific fertility are not tightly linked (Low and Clarke, 1991a). Marriage probably served both reproductive and economic functions (cf. Goody 1983), and reproduciive and economic gains could, perhaps, be traded. If women's reproductive value was important biologically in mate choice (though it nieed not have any perceived importance to people themselves), several predictions foilow:

(a) Womeñ should tend to marry for the first time at younger ages than men.

(b) Marriage rates for women should fall quickly as reproductive value declines.

(c) Fewer widows than widowers should remarry, and women should remarry at younger ages than men.

(d) The difference in age between spouses should increase in second and 
subsequent marriages, as men marry younger (higher reproductive value) women.

(e) The fertility of men's second marriage s should be greater than the fertility of women's second marriages, as they marry relatively younger women in second and subsequent marriages.

2. If reproductive value, linked to age, is important for women, while resource controi is more important than age for men, women's rcproduction is likely to correlate less well than men's with wealth, power, or status (see Prediction $\mathbf{4}$ for the comparable prediction for men). Instead, even in a cultural milieu such as nineteenth century Sweden, in which marriage ages are late, and divorce and remarriage are low', women who marry earlier are likely to have higher lifetime fertility than women who marry later; death and men's remarriage will dilute correlations between spouses.

3. When the resource base is extensive, pressure on it is limited, and individuals can acquire plentiful resources, men with greater resources should produce more children than those with fewer resources. This prediction will not hold when the role of children is itself that of a resourcelabor to acquire land (cf. Johansson 1987). However, in nineteenth century Sweden, access to health care was relatively egalitatian, and, while sons often worked on a father's farm, there is no evidence that sons' labor assisted parents in obtaining additional land above that used for the sons themselves.

4. Because of the interplay of resource (male) and reproductive (female) values, mer. controlling mure resources should be more likely se marry, and should marry younger womer, than cio men with fewer resources. That is, if high reproductive value is seen as desirable, men with greater economic resources may be able to command women with higher reproductive vaiue in the marriage market; one can also say that women with high reproductive value are free to choose men with greater resources. A corollary is that men with few resources might choose to marry older women with greater resources when they can, explicitly trading reproductive value for resource value.

5. When a major nonpartible resource becomes limiting, family size should decrease for resource-holding families, and family size should become more equal across the society. Thus, if heritable resources are important to children's (especially sons') eventual success, as these resources become restricted:

(a) Affected families seem likely to restrict family size to ensure effectiveness of remaining resources (if significant parental investment is required for children's success, as resources are constricted, and minimal required investment does not decrease, the number of investments must increase).

(b) Migration rates should increase, and these rates should differ for sons (but not daughters) of different status families, if sons' success is more dependent than daughters' on resource control. Similarly, 
(c) Migration rates should increase for sons of different parity within resource-holding families. Sons not inheriting resources may succeed better by ieaving the parish, rather than remaining as no resource holdiing men in their home parish. Thus, resource-holding sons should remain, using their resources to enhance their lifetime success, as did their fathers, while noninheriting sons should profit from "entrepreneurship" elsewhere.

6. For families with resources to bequeath, unequal distribution of resources among children may be an advantageous reproductive strategy (cf. Hartung 1982, who found male-biased inheritance rules in polygynous societies-in which resources could be used to acquire additional wives). Though this cannot be measured directly without examination of wills (cf. Smith et al. 1986), if resources are important to men's reproduction. $\forall$ ien unequal distribution occurs, unequal :eproduction should be seen with parity (birth order) in sons but not daughters (e.g., Low 1990b, Low and Clarke 1991a).

7. Men and women, if they use resources differently, may well be affected differently by the number and sex of their siblings. That is, whenever sons compete for heritable resources, as the number of brothers increases, men's reproductive success should drop, because parents' abilities to endow those sons decreases (e.g., Low and Clarke 1991a). The evolutionary ecological equivalent of this hypothesis is that of local resource competition (E.g., Alexander and Sherman 1977; n.b. in nonhumans, among males, the "resource" is typically mates). Women, more likely to be called upon to care for their siblings ("helpers at the nest," e.g., Woolfenden and Fitzpatrick 1984) or aging parents, might end up marrying later and having fewer children as their number of siblings, regardless of sex, increases. Child care might be expected to affect earlier-born daughters more strongly than laterborn, while care of aging parents might affect later-born daughters.

8. Because humars, like most mammals, have a polygynous evolutionary history reflected in physical dimorphism (males are larger than females, carried slightly longer in utero, nurse more and more frequently, and overall, are more expensive energetically to produce), the longest inter-birth intervals should be son-son.

9. There may well be a shift in sex ratio of children born to older versus younger mothers. If older mothers are in sufficiently good condition to invest maximally, sons, with their potentially greater reproductive success (even in "monogamous" societies), should become more prevalent with increasing age of mother; that is, as mothers come closer to the end of their reprociustive lives (and their reproductive costs and benefits converge on those of semelparity), they should invest more in each reproductive bout-make sons (e.g., Williams 1966: 174). In most other mammals, females' declining condition makes this impossible; if this is true for women (if older women are in poorer nutritional condition), older moth srs should be more likely to give birth to less costly daughters (Trivers and Willard 1973). 


\section{SAMPLE AND METHODS}

Analyses were done for the period 1824-1896. Data were obtained from the Swedish Demographic Database, Umeå University, Umeå, Sweden, which contains, for seven nineteenth century Swedish parishes, computerized demographic and historical data derived from Lutheran Church examination registers, birth and baptismal registers, marriage registers, migration registers, and death/burial registers (Demographic Data Base 1986). The structure of the data makes it possible to do longitudinal analysis, following family lineages, s:milar to the Ortissippenbuch used by Knodel (1988).

The sample for this study comprised all male founders $(n=191)$ married between 1824 and 1840 in seven parishes and all their male $(n=4035)$ and female $(n=3867$ ) biological descendants (Fig. 1, Table 1). The original sample was struciured this way for other analyses (Low 1989b, 1990b; Low and Clarke 1991a, b; Low et al. 1991). Biological descendants were defined as those whose parenthood, through birth or baptismal records, could be reliably established; the estimate is thus conservative, sirce some records

FIGURE 1. Location of the study parishes.

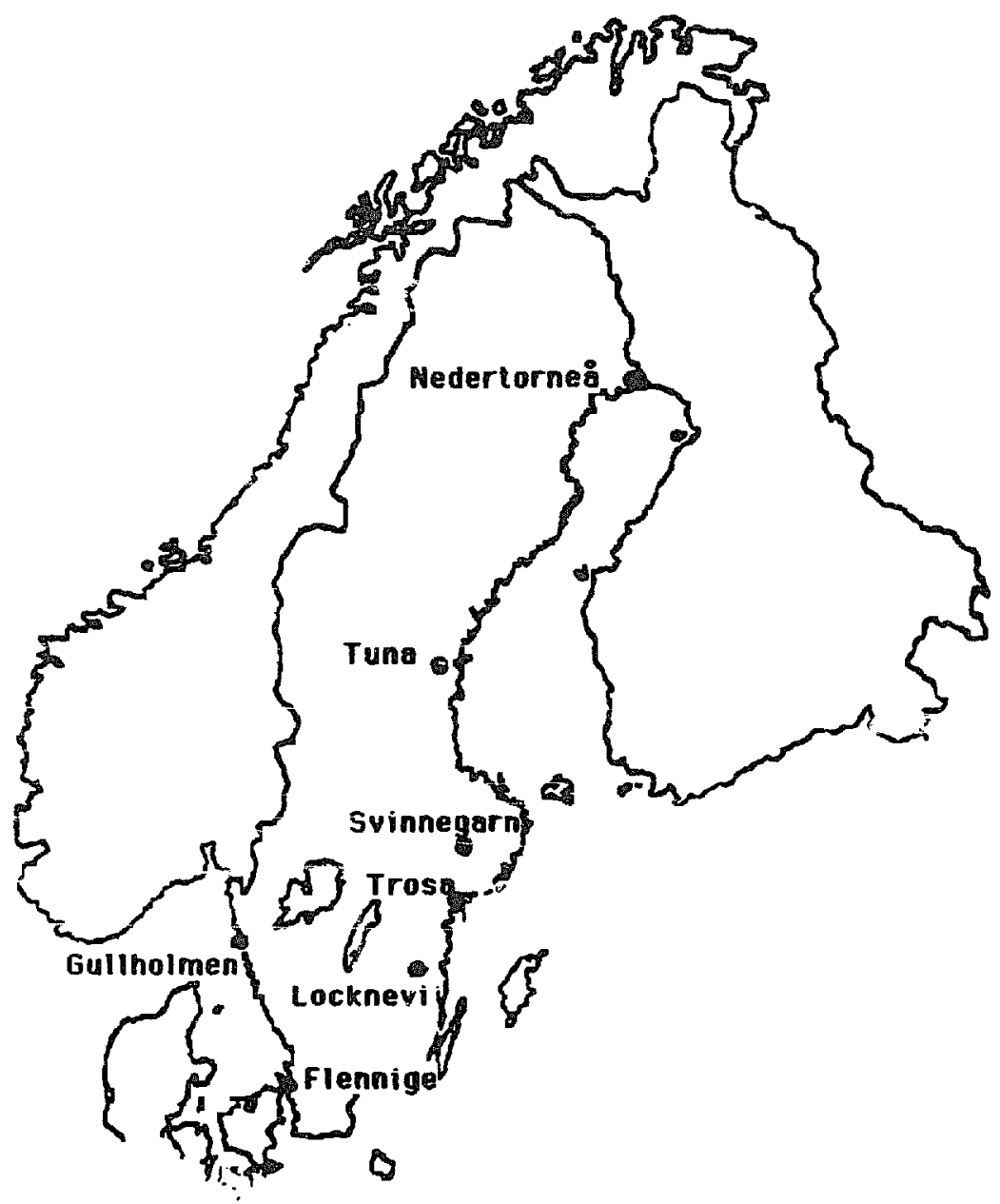


Table 1. Summary Reproductive Patterns for 3,867 Wonsen and 4,035 Men Born in Seven Swedish Parishes, 1825-1896 (Generations 2-5).

\begin{tabular}{|c|c|c|c|c|c|c|c|c|c|c|}
\hline Parish & Sex & Born & $\geq 14$ & $\geq 14, \mathrm{R}$ & NBC & $\mathbf{R S}_{10}$ & Marr & Age & $\mathrm{NBC}_{\mathfrak{m}}$ & $\mathrm{RS}_{\mathrm{IOm}}$ \\
\hline \multirow[t]{2}{*}{ Locknevi } & $\mathbf{M}$ & 887 & 482 & 227 & $2.6 \pm 0.2$ & $2.1 \pm 0.2$ & 148 & $27.3 \pm 0.4$ & $3.7 \pm 0.2$ & $3.0 \pm 0.2$ \\
\hline & $\mathbf{F}$ & & & & & & & & & \\
\hline \multirow[t]{2}{*}{ Gullholmen } & $\mathbf{M}$ & 372 & 214 & 187 & & $1.6 \pm$ & 95 & $8 \pm 0.4$ & & \\
\hline & $\mathbf{F}$ & 400 & 253 & 19 & & $2.2=$ & 107 & & & \\
\hline \multirow[t]{2}{*}{ Tuna } & $\mathbf{M}$ & 92 & 429 & 30 & & & 194 & & & \\
\hline & $\mathbf{F}$ & 90 & & 26 & & & 200 & & & \\
\hline \multirow[t]{2}{*}{ Nedertorneå } & M & 129 & 519 & 381 & & & 188 & $25.9 \pm$ & & \\
\hline & F & 1227 & 537 & 340 & & & 195 & & & \\
\hline \multirow[t]{2}{*}{ Svinnegarn } & $\mathbf{M}$ & 110 & 59 & 17 & & 1.0 & i4 & & & \\
\hline & $\mathbf{F}$ & 92 & 45 & 13 & & 0.7 & 11 & \pm 0.9 & & 1.1 \\
\hline \multirow[t]{2}{*}{ Trosa } & $\mathbf{M}$ & 247 & 128 & 49 & & & 32 & & & \\
\hline & $\mathbf{F}$ & 226 & 118 & 39 & 4.1 & & 35 & $25.2 \pm 0.9$ & & \\
\hline \multirow[t]{2}{*}{ Flennige } & $\mathbf{M}$ & 199 & 102 & 38 & & $1.5 \pm$ & 25 & $30.0 \pm 1.4$ & $4.8 \pm$ & $3.2 \pm 0.7$ \\
\hline & $\mathbf{F}$ & 177 & & 40 & & & 26 & $26.6 \pm 1.0$ & $4.3 \pm 0.9$ & $3.3 \pm 0.9$ \\
\hline
\end{tabular}

$\geq 14$ = attained age of $18 ; \geq 14, R=$ attained 15 years, and the full reproductive history is available; NBC = number of children bom per woman ur man; $\mathbf{R S}_{\mathbf{1 0}}=$ number of children living to age ten; Marr = number in the sample who married; Age = average at marrigage. NBC and $\mathrm{RS}_{10}$ are restricted to individuals whose entire lives were spent in the parish (no recoro loss).

might be lost, and some fathers of illegitimate children might not acknowledge them. This sample structure also means that not all individuals could be compared in all tests. For example, comparisons between women and men required restriction to generations 2 and later, for no women existed in generation 1. Similarly, the new measures $\mathrm{NBC}$ and $\mathrm{RS}_{10}$ (below), generated to examine lifetime fertility, had to be restricted to individuals completing their reproductive lives in the parish. Thus a woman who had two children and was aged 30 when the sample ended in 1896 wnold be inclided in calculations of age-specific fertility, but exclucied from the calculation of lifetime fertility.

For all individuals in the sample, the following data were collected: birth date, legitimacy status, parity (birth order), father's best occupation, number of marriages, age at first and any subsecuent marriages, spouse's identification, spouse's best occupaiion, number of children born, cates of children's births and deaths, date of death or loss of record, and type of record loss (è.g., death or migration out of the parish). For men, it was possible in addition to specify own best occupation.

Analyses included childhood and adult survivorship and mortality, and measures of fertility. Childhood measures were categorized by father's occupation or mother's age at the child's birth, depending on the analysis. Adults were defined as those individuals who survived to 15 years; 16 was the youngest age at which an; wonan in this sample married. Thus comparisons were for all men or women born reaching age 15 , or all who married.

Percent nuptiality (percent of women over age 15 who were married) was calculated, but because this study covered 73 years (1824-1896) and was based on a cohort, rather than covering a short period of time or sampling all individuals resident in the parish at any moment, nuptrality was tracked 
over the study period. Inter-birth interval was calculated for each woman who had more than one child.

The standard measure of age-specific fertility, summarizing the reproduction of women in different age categories, was calculated. Total Fertility Rate, the sum of all age-specific fertility, and Net Reproductive Rate, the average contribution of daughters by women, given fertility and mortality schedules, were also calculated (here reported per thousand women; Palmore and Gardner 1983). Because these measures are based on mother's age at the child's birth, and generation 1 contained only men, they were calculated for generations 2-4. Many studies focus on families to analyze fertility, but siice remarriage and illegitimacy complicate these issues, and since the hypotheses make different predictions for men and women, it is important to consider some aspects of reproduction separately for individuals of the two sexes.

Standard demograph:c measures are designed to allow predictions about populations, but they have several difficulties for a study such as this. These measures are based on women, and any assumptions for men or families ignore death, divorce, and rernarriage. Because they are aggregate measures, they might vary depending on the relative representation of sub-groups, if sub-groups behave differently. Further, the strength of inter-group differences is difficult to assess, beruse intra-group variation is not reflected in the aggregate statistics.

Because the focus of thi. study is individual and familial patterns, new measures reflecting variance $a$ nd allowing for the testing of strength in intergroup differences were used in addition to standard measures. I was able to measure for many individuals actual lifetime fertility (NBC: number of biological children, i.e., children born to the individual). This measure is analogou to NRR (while measuring offspring, rather than daughters, it takes maternal survivorship into account, unlike TFR); however, it is based on individual patterns, and carries a variance. In addition, the survivorship $\left(\mathbf{S}_{\mathbf{1 0}}\right)$ and mortality rates of the children of a parent to age ten, and the resulting number of children alive at age ten $\left(R S_{10}\right)$ were calculated. Ideally, one would like to calculate these two measures to children's marriages, but the social circumstances were that many children moved out of the family, taking jobs in other households (sometimes even in other parishes) much earlier than they married, so that ambiguous cases could result. Thus, age ten was chosen as an age on the threshold of adult independence.

The measure $\mathbf{R S}_{10}$ is a reflection of "net success" for each individual, the result of the interaction of other measures analyzed here: age at marriage, age at birth of first child, marital fertility, inter-birth interval, and childhood survivorship. It is a summary measure reflecting an individual's net reproducti ve success as a function of his or her particular fertility and survivorship. NBC, $\mathbf{R S}_{10}$, and survivorship rates of children were calculated per mother or father, rather than as population averages. Such measures are 
important in making comparisons among individuals, family lineages, or reproductive strategies (cf. Williams 1966; Hughes 1986; Low 1989b, 1990b).

$\mathrm{NBC}$ and $\mathrm{RS}_{10}$ were calculated for every individual reaching 15 for whom full records were available. Both $\mathbf{N B C}$ and $\mathbf{R S}_{10}$ tend to be somewhat lower than hypothetical measures such as TFR, because some individuals died before completing their full potential reproductive lifespans. If there is any difference in the reproductive patterns of people who leave the parish and those who stay, NBC and $\mathbf{R S}_{10}$ will also differ from NRR (or rather, NRR times 2). NBC and $\mathbf{R S}_{10}$ were restricted to those adults living their lives within the parish. Age-specific fertility, NRR, and TFR do not require this restriction.

These new measures reflect somewhat different aspects of reproductive behavior, and can deepen our understanding, when added to TFR and NRR. TFR is never assumed to be a very realistic reflection of population growth; it will always overestimate growth. NRR, by assigning average age-specific fertility mortality for adult age classes, may come somewhat closer; because it measures only daughters, age-specific or lifetime biases in sex ratio can be problematic. Neither measure gives any reflection of variability within any class, as NBC and $\mathbf{R S}_{10}$ do. Further, such variation can be important not only in comparing categories (age or occupation, for example) but also when the average behavior is not close to the modal behavior (i.e., when the distribution is skewed). Thus, when Low and Clarke (1991a) compared reproductive patterns in four parishes, using the same sample to derive each measure, the rank order of the parishes changed, depending on whether the standard or individually-based measures were used.

Survivership was analyzed in two ways. For comparisons between the sexes (restricted to generations 2 and greater), or comparisons hy marital status or occupation, survival analysis (BMDP:11) was used. Sometimes differences are more pronounced early or late in life. Both generalized Wilcoxon (Breslow) and Savage (Mantel-Cox) results are given. The generalized Wilcoxon (Breslow) test gives greater weight to events early in life; the generalized Savage test (Mantel-Cox) weights events more evenly (and thus may be influenced by differences at the end of the period, when fewer individuals remain). For comparing the net reproductive success $\left(\mathrm{RS}_{10}\right)$ of different categories, the contribution of within-family survivorship $\left(S_{10}\right)$, as well as fertility (NBC) was assessed. Thus, sometimes net family size $\left(\mathrm{RS}_{10}\right)$ did not change between generations or when occupations were compared, but (compensating) differences in both fertility and survivorship existed.

Average survival and reproductive patterns frequently vary among different occupations (e.g., Eriksson and Rogers 1978; Rogers 1980; Haines 1985), though with aggregate measures, the strength of these differences is difficult to assess. To reflect occupation, the approximately 10,000 occupational codes derived by Erik Söderlund (Swedish Demographic Data Base, Haparanda, Sweden) were clustered into five categories: upper middle class (those with several servants, ownership of factories or large businesses, and/ 
or large amounts of land); lower middle class (e.g., small businessmen, artisans, professional soldiers, with one or a very few servants), bönder (farmers who owned their land), torpare (farmed, had a long-term to lifetime interest in the land, but could not will it; cf. cottars); statare (migrant farm laborers) and proletariat (household servants, retired servants, indigent poor) were lumped as a fifth category. These categories approximate the standard classification for upper and lower middle class and farmers, although for most studies (e.g., Brändström 1984), the torpare are 'umped in with household servants and statare as proletariat. For most analyses, occupation was treated as categorical, but for comparisons of "best" occupation, the standard assumption was used: for example, if a man was a torpare during one period, and a bonde during another, the "best" occupation was listed as bonde. Women in nineteenth century Sweden typically had no independent occupation after marriage, and their occupations prior to marriage (most commonly piga, household maid) never exceeded their father's occupation in status. Thus the higher-status occupation, own-orhusband's, own-or-father's, was used; these overwhelmingly reflected husband's or father's occupation.

Statistical analyses were done using the MIDAS and BMDP statistical packages on the Michigan Terminal System. For analysis of marital and occupational patterns, the sample was restricted to individuals surviving past age 15, in order to separate the effects of childhood mortality from effects of occupational status, age at marriage, and other adult measures. Analysis of variance was restricted to problems (e.g., survivorship rate within the family, comparisons of inter-birth intervals) for which data were continuous and normally distributed (Conover 1980). Although ANOVAs are typically used for analysis of number of children, the distribution is clearly non-normal (i.e., many more families have one child than have the maximum number), so the Kruskal-Wallis statistic (Conover 1980) was calculated.

\section{RESULTS}

\section{Inter-Parish Variation}

Total fertility rate for all women, percent nuptiality, age-specific fertility, and the individual fertility measures $\mathrm{NBC}, \mathrm{RS}_{10}$, and within-family survivorship rate varied among the parishes (Low and Clarke 1991a). These differences may reflect aspects of economic and resource variation among the parishes. Only four parishes, Nedertorneå, Tuna, Locknevi, and Gullholmen, had sample sizes sufficient for separate analysis.

Nedertorneå, the most northern parish (Fig. 1), had at all ages the highest age-specific fertility (Fig. 2), the highest total fertility rate, but a net reproductive rate comparable to other parishes (Low and Clarke 1991a). Nedertorneå was a poor farming parish, with low-nutrient and somewhat 

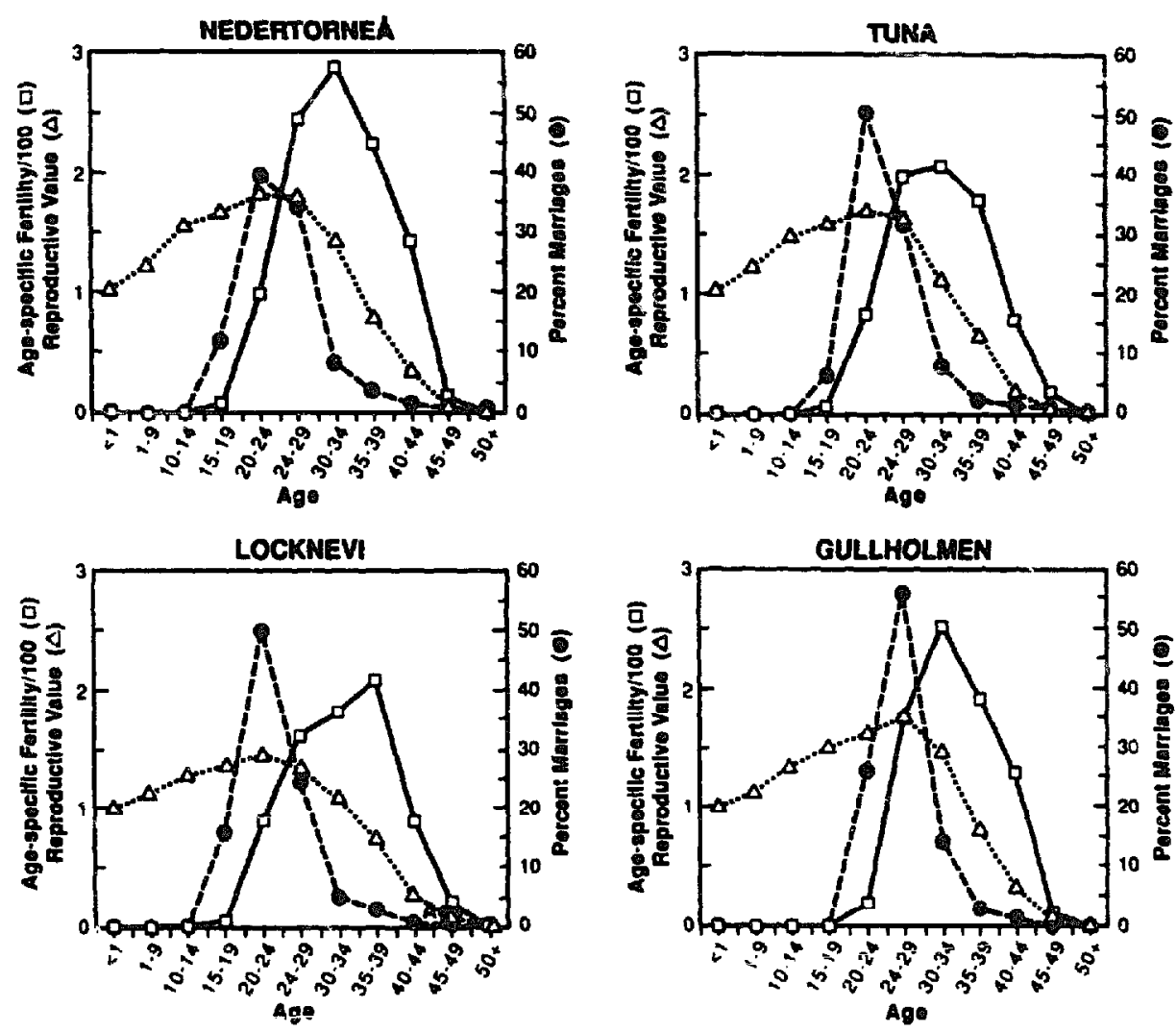

FIGURE 2. Age-specific fertility and reproductive value are useful for finding different patterns. Reproductive value, a function of women's age-specific fertility and age-specific mortality, may have importance in marriage patterns. Peak age at marriage is shown; it never follows the peak of reproductive value, but is not linked to age-specific fertility (e.g., see Locknevi, in which women marry early, but show late peak fertility). See text for further discussion.

acidic soil, and short summers. Throughout the first half of the nineteenth century, the Finnish habit of feeding infants on cow's milk rather than nursing was common (Brändström 1984). As a result, infant mortality was high (Fig. 3), and inter-birth intervals were short. The average lifetime completed fertility of all women 15 and older was the highest of any parish (Table 1); however, because infant mortality $u$ as high, the number of children surviving to age ten was little higher that. in other parishes (Table 1). Similar patterns are apparent for married women (Table 1; Low and Clarke 1991a).

Tuna parish was a farming parish in central Sweden (Fig. 1). Its population rose from approximately 1200 to approximately 3300 during the nineteenth century. It experienced rapid industrialization during the study period. Many men worked in the iron foundry (Matfors Bruk) as well as farming, and this influenced patterns of family size and migration (Low and Clarke 1991b). TFR and NRR were more moderate than in Nedertornea (Table 1; Low and Clarke 1991a). Women's age-specific fertility was rather constant from ages 25 to 39 (Fig. 2). Fifty percent of all marriages occurred 


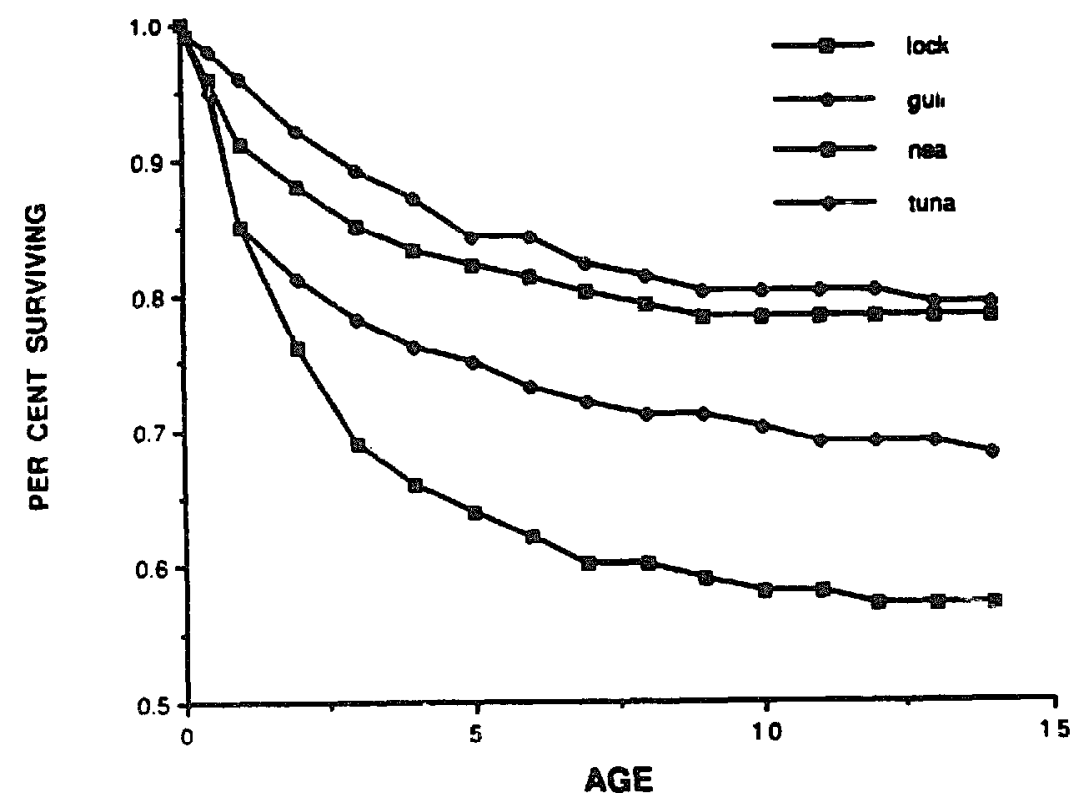

FIGURE 3. Survivorship of children born in the fcur largest parishes. Nedertorneå, in which fewer children were breast-fed, had the lowest survivorship rate. In all parishes, the survivorshin of girls was higher than that of boys.

between women's ages 25-29. Eighty-one percent of all women for whorn full reproductive histories exist married, although at any one time, the maximum percent of women residents and over 15 years old who were married was $60 \%$. The average lifetime completed fertility (NBC) of all women over 14 was approximately 3.3 ; the number of children surviving to age ten $\left(\mathrm{RS}_{10}\right)$ was 2.6 (Table 1).

Locknevi parish was similar to Tuna parish economically, although probably more limited: a farming parish with a sawmill that flourished in the early part of the nineteenth century (Gerger and Hoppe 1980). Farming opportunities were limited, however, to a large North-South valley of arable land, and during the nineteenth century the population rose, then declined (Demographic Data Base, Basstatistik; Low and Clarke 1991a). Large property owners and upper middle class families appear to have sold properties and led the out-migration (Low 1989b), so that landholdings became progressively smaller. Fertility patterns for women were rather similar to those in Tuna parish (Table 1; Fig. 2). Women married relatively young in Locknevi (Table 1); however the age-specific fertility (all women) peaked somewhat later, at age 35-39. The long delay between peak age at marriage (age 20-24) and peak fertility (age 30-35) suggests that fertility was delayed (Fig. 2; cf. Knodel 1988).

Gullholmen is an island parish (Fig. 1). Here, most people earned a livelihood by fishing, and the catches could vary considerably from year to year. In the face of this economic uncertainty, people married rather late. There was little difference in status, as reflected by occupational codes. The 
average age at marriage for women was 26.7 years, and the percent of women marrying was relatively low: of all women for whom full reproductive histories are available, $42 \%$ married. TFR and NRR were slightly lower than in Locknevi; population growth through the period was slow (Low and Clarke 1991a). Age-specific fertility peaked sharply at 30-34 years (Fig. 2). Although women's completed lifetime fertility was low (Table 1), survivorship of children was high, and the number of children reaching age ten was quite high (Table 1; also see Low and Clarke 1991a). In fact, the number of children alive at age ten for married individuals was the highest of the four parishes (Low and Clarke 1991a).

It is tempting to speculate that women's late age at marriage, low rate of marriage, and low overall fertility (though high, late marital fertility) in Gullholmen arose from the uncertainty of income from fishing. Sundbärg's (1904: 675-676) summary of the quintals of fish (mostly herring) exported from Bohuslan (including Gullholmen) for the years 1877-1903 shows a coefficient of variation of 1.04 , rather high. However, we have no data on fertility early in the century, and actual fisheries catch records from the period in this study would be helpful. Similarly, in Nedertorneå, while the way in which children were fed (Brändström 1984) was clearly the cause of the high infant death rate, it is not clear what links high mortality to high fertilitywhich is cause and which effect, what proximate mediators (no lactation amenorrhea, deliberc attempts to replace children) were in operation. Some preliminary inferences are possible, however.

\section{Resources and Men's Reproduction}

In this study, 1745 males lived to be at ieast 15 years old. Of these, 1435 married, at an average age of 27.5 years. For men, occupational status and/ or land ownership were likely to be the most important predictors of reproductive behavior (Prediction 3; Low 1989b, 1990b; Low and Clarke 1991a). Patterns varied among parishes, however, and with historical events. For example, in Locknevi Parish, but not in other parishes, during the decade 1841-1850, few people in the sample married, and their fertility was lower than for individuals married in other decades (Low 1989b). Examination of historical documents (Uterström 1957) revealed that a series 0 ? difficult agricultural years succeeded each other in Locknevi during that decade. In Locknevi, men's best occupation was associated with differential likelihood of marrying (Low 1989b). Sixty-four percent of statare and proletarian men failed to marry, compared to thirty-four percent of lower middle class men. Early in the study period, both the number of children born during a man's lifetime and the number of those children surviving to age ten varied significantly with a man's best occupational status: both decreased with decreasing status (Low 1989b). Prices rose (Jörberg 1972), purchasing power remained low (Low and Clarke 1991b); and the fertility of richer men (here defined as upper middle class, lower middle class, and bönder) declined to 
that of poorer men (torpare, statare, and proletariat; also see Low 1989b; Low and Clarke 1991a). Aggregate analyses also suggest that fertility followed economic conditions (Low and Clarke 1991b). Similarly, Wrigley and Schofield (1981) noted that marriage rates and fertility in England followed agricultural and economic conditions to some extent.

More resource-holding men in all parishes married younger women than nonresource holding men (Prediction 4; $n=1413, \bar{x}=25.4 \pm 5.7$ versus $26.3 \pm 6.4, t=2.6, p=0.009$ ). In a similar study, Voland and Engel (1990) attributed this to female choice; however we term it, it is clear that a coyrelation exists between men's resource value and women's reproductive value. In this study, the difference is not simply linear: upper-middle class men married women 24.5 years old on average, lower-middle class men married women 25.0 years old, bönder married women 25.7 years old, torpare married women 26.9 years old, statare and proletariat married women 25.5 years (ANOVA: $n=1411$; d.f. $=4,1406 ; F=4.87 ; p=0.0007$ ). The fact that torpare married older women is intriguing in light of Drake's (1969) report of torpare during the same historical period in Norway explicitly stating that they sought older women as wives, women who had accumulated household goods and acquired the skills for managing households. Similarly, Mitterauer and Sieder (1982) found that journeymen occasionally married the widows of their tradesmasters in Austria. Thus, while we predict women to marry at younger ages than men in general (Prediction 1(a), and men with considerable resources can marry (younger) women with high reproductive value; men with few resources may explicitly trade reproductive value for economic value in a wife (Prediction 4 corollary). This is further reflected by the contemporary view that daughters of upper-middle class men were considered women (marriageable) at eighteen years, while daughters of poorer men were not considered marriageable until years later, in their midto-late twenties (Drake 1969). Hughes (1986) found similar patterns with men's wealth and women's reproductive vaiue.

Comparing spousal ages in men's first and second marriages, the mean difference in spouses increased (Prediction 1(d)): for men married more than once, the age difference in the first marriage was +0.45 years, while the age difference in the second marriage was -10.6 years $(n=121, t=9.91$, $\mathrm{p}<0.0004)$. That is, when men remarried, they tended to marry not women of their own age, but younger women (again, of higher reproductive value). This undoubtedly contributed to the greater fertility of mon's second marriages, compared to women's (below).

Patterns varied between the first and second generations (Low 1989b, $1990 \mathrm{~b}$ ), among parishes, and even among decades of marriage within the second generation. Whenever sufficient variation in resource base existed, men's reproductive success correlated with resources (Prediction 3). In Locknevi Parish, during the first generation (men married 1824-1840), men's reproductive patterns varied with their occupational status (Low 1989b). Little occupational mobility was apparent for men. This would suggest, other 
things being equal, that the reproductive differentials would accumulate over time. However, by the second generation in the sample, during the period of apparent resource constriction in Locknevi parish as land became scarcer, and parcels became smaller, reproductive differentials associated with occupation disappeared. Family size and rate of production of children decreased during this period as well, reflecting the resource constriction (Low 1989b; Low and Clarke 1991a, b).

In Tuna Parish, men's best occupation was associated with differential likelihood of marrying (Low and Clarke 1991a). In this parish, as others, marriage was important to lifetime reproduction. Married men had significantly more (acknowledged) children than unmarried men, and significantly more children surviving to age ten (Low 1990b; Low and Clarke 1991a). In Tuna, land ownership records were available; landowners were more likely to marry than nonlandowners (Prediction $\hat{4}$; Low 1990b), and they married younger women (Prediction 4; Low 1990b). Men who owned land had more children than men who did not own land (Prediction 3); in part this was due to the higher probability of marrying for landowners, but comparisons of married men sustained this pattern (Low 1990b). Voland (1990) also found that the family lineages of landed peasants in Germany consistently fared better than the population mean.

These patterns are consis ent with the hypothesis that resources contribute to reproductive success (Hypotheses 3, 4, 6; Low 1989b, 1990b), but not consistent with the children-as-resources/producers hypothesis (Hammel et al.. 1983, Johansson 1987, and others). If children were perceived by parents as producers in agricultural work, not only land owners but land workers (e.g., torpare, statare) they should have larger families. Landowners had larger families no matter what the economic times; and landowners' family size showed less variance than that of nonlandowners (Low and Clarke 1991b). Perhaps land ownership provided a buffer against hard times.

In Tuna, men who owned large amounts of land often had landless sons as well as sons who also owned land. Earlier-born sons were most likely to remain in the parish, to own land as adults, to marry, and to have more children than their later-born, landless brothers (Prediction 6; Low 1990b; see Boone 1986, about similar problems of unequal investment in, and success of, sons of wealthy medieval Portuguese families). Thus, reproductive differences were associated with parity (birih order) for men (Prediction 6; Low 1989b, 1990b; Low and Clarke 1991a). If ressurces are important in raising children successfully, parents face the problem of optimum allocation of resources among their offspring, particularly when nonparible resources such as land are involved. It would not be surprising to find unequal distribution of resources among children following differences in sex and birth order, despite Swedish legal constraints requiring equality of inheritance.

In Gullholmen, there was little variation in occupational status, probably related to the limited land resources of the island and the dependence of most men on fishing, a risky and unpredictable occupation. There were only 
three upper-midule class (UMC) men and two proletariat men in the sample; thus these occupations were excluded from most analyses. Men's survivorship was related to their occupation (Low and Clarke 1991a). In Generation 1, there was no pattern to a man's occupational status and his age at marriage; in Generations 2-4, lower-middle-class (LMC) men tended to marry slightly later than bönder (Low and Clarke 1991a). The age at which men first married was loosely related to lifetime fertility, in contrast to other parishes (Low and Clarke 1991a).

In Generation 1 in Gullholmen, a man's occupation was related to the number of children born during his lifetime, but not the number of those children surviving to age ten; in generations $2-4$, no differences were apparent (Prediction 3; Low and Clarke 1991a). Remarriage was not important to men's lifetime reproduction; only five men married mure than once (maximum number of marriages $=2$ ). Four of these five men were bönder (Low and Clarke 1991a).

In Nedertorneå, the interaction of resources and reproductive patterns was complex, influenced by at least two sorts of historical particulars. First, the occupational status measure shows a great range, but this is due to an action by the central Swedish government early in the nineteenth century in moving upper-level civil servants to the outpost town of Haparanda, to shore up the local economy (e.g., Brändström 1984), and the reproductive patterns of local families and immigrant families are not separable in these data. Second, survivorship of infants was low, due to the habit of feeding infants cows' milk, which often was contaminated, rather than breast-feeding them (Brändström 1984). In the $1840 \mathrm{~s}$, a doctor came to Haparanda, beginning a campaign to reinstitute breast feeding. Because he worked mainly with upper-middle class families, and in the town of Haparanda rather than the surrounding countryside, there is great variation in inter-birth intervals and survivorship; thus fertility and family size are tied to location, class, and time. Location was not analyzable in this study. Thus, for this sample, there were no significant differences in either fertility or children alive at age ten (Low and Clarke 1991a). Brändström (1984), who was able to partition the effects of residence as well as class, found significant fertility and survivorship differences with class in the predicted direction (Prediction 3), and with residence (town versus countryside). Both of these differences probably relate to the doctor's "rounds": principally in the town of Haparanda among upper middle class families, whose servants and friends also benefited from his counsel. Neither Brändström nor Low and Clarke were able to examine any relationships with land ownership and fertility.

Thus, for these four parishes, in Tuna and Locknevi, when resources were apparently abundant, resource control correlated with fertility and children alive at age ten (Prediction 3). In Locknevi, when resources became constricted (Gerger and Hoppe 1980, Low 1989b), migration increased and reproduction fell (Prediction 5). In Tuna, there was no evidence of resource constriction, and no decrease in fertility during the period (Low 1990b). In 
Gullholmen, there was little difference in either occupational status or fertility and family measures. In Nedertorneå, no differences in fertility with class existed in this study, but historical factors as well as resources may have influenced fertility; in another study (Brändström 1984) which partitioned these efferts, occupational status was significantly related to fertility.

These differences may be further related to ecological and resource differences. In many areas in (mainland) southern Sweden, single crops dominated the economy. Rye and corn were major crops; corn was particularly labor-intensive, influencing broad sectors of the population. Bad harvests created real hardships, reflected in prices and purchasing power. In the north, agriculture was more mixed, and was consistently supplemented by fishing and forestry. Thus, failure of any particular crop was likely to have less impact on people's lives. Harvest and price information alone are insufficient reflections of conditions in some areas (e.g., Low and Clarke 1991b). Sundin (1976), in an analysis of theft and penury in Sweden, found that famines and high food prices were good predictors of theft in the counties relying on one principal agricultural crop. However, in "mixed" counties (e.g., Kalmar, which includes Locknevi Parish), the correlation was weaker. In the northern "forest" counties (e.g., Västernorrland, which includes Tuna Parish, and Norrbotten, which includes Nedertorneå), forestry and ironworks as well as hunting and fishing supplemented agriculture, yielding a diversified economy; in these counties, Sundin found no significant relationship among crop yields, cost-of-living indices, and theft rates. Thus, the weaker patterns in the north are not surprising (Low and Clarke 1991b).

\section{Resources and Migration}

Economic conditions influenced overall migration patterns: in 1879, when Matfors Bruk (a major employer) closed in Tuna Parish, a great out-migration was evident, and for some years thereafter (involving the reopening of the Bruk) migration fluctuated far more than in previous years (Low and Clarke 1991b). In this sample, unfortunately, the reproductive lives of migrants could not be followed, and of course, the reproductive success of migrant sons and daughters is important to the relative success of any lineage (e.g., see Voland 1990). The children of migrants to reiatively new areas typically show greater fertility than those to densely populated areas (e.g., Easterlin et al. 1978).

Families responded differently to economic fluctuations. Migration was related to father's occupation (Prediction 5(b); Low 1989b, 1990b; Low and Clarke 1991a, b; Clarke and Low in press). Sons and daughters of all other classes than bönder were more likely to migrate (Clarke and Low in prep; families of bönder may have fewer options for movement because of ties to the land). Men typically moved in search of work, while women moved to join a future husband's family (e.g., Low 1989b; Clarke and Low in press). Within-family differences may influence probability of migration, perhaps 
through differences in access to resources (informal primogeniture, sanctions against illegitimate births). Differences at the family level may not be apparent at higher aggregate levels of analysis. When population-level analyses mask diversity in sub-group behaviors, differences and similarities between and within populations may be overlooked. Further, inappropriate theories of causality may be derived (see Hawkes and Charnov 1988).

Perhaps related to the different causes of men's and women's migrations, parity was more important for men's migration than women's (Prediction 5(b); Low and Clarke 1991a; Low 1989b, 1990b), and more specifically for sons of families with resources to bequeath. When fathers had resources to bequeath (i.e., were UMC, LMC, bönder), earlier-born sons were likelier to remain in the parish, and have larger families; when fathers were torpare, statare, or proletariat, there were no such differences with parity (Low and Clarke 1991a). Earlier-born sons of men with resources were less like; to leave the parish, had more children, and had more children alive at age ten, than later-born brothers. No parity-based pattern was apparent for sons of men with fewer resources to bequeath (Low and Clarke 1991a; also see Low 1989b, 1990b). No pattern was apparent for daughters with parity, regardless of father's status.

\section{Reproductive Value and Women's Patterns}

Of the 3867 women born in this sample, 1930 remained in the sample to age 15. For 1037 women complete reproductive histories were available. For these women, the average lifetime fertility (NBC) was 2.82 (range 0-20); the number of children alive at age ten (family size; $\mathrm{RS}_{10}$ ) was $1.7(0-14)$. Seven hundred and sixty women had at least one child; the family size for these women averaged $3.9(1-14)$. Patterns varied among parishes somewhat (above, Table 1).

Seven hundred and thirty-nine women married, at ages ranging from $16-54(\bar{x}=25.0 \pm 4.94)$. This represents $71 \%$ of the women for whom reproductive histories were available. Six hundred and thirty married women had at least one child. Fertility was much higher for married than unmarried women. Of 7626 births, 7267 (94.7\%) were legitimate, 360 illegitimate, and 49 during the period of betrothal. Married women averaged 4.0 children born and 2.5 children alive at age 10, compared to 0.7 born and 0.3 alive at age ten for women who did not marry. This represents the effect of illegitimacy rates that ranged from 1.3\% (Gullholmen) to over 7\% (Nedertorneå and Tuna).

Women married earlier than men (Prediction 1(a); $25.0 \pm 0.2$ years versus $27.5 \pm 0.2$ years; $n=1434, t=9.75, p<0.00001$ ), and only $4 \%$ of women married after the peak of reproductive value (Prediction 1(b); Fig. 2). Women who married earlier, not surprisingly, tended to have more children during their lifetimes than women who married later (Prediction 2); when marriage is important to realized fertility, age at marriage then becomes 
important. This, of course, raises the question of why, except in resourcerestricted (e.g., Locknevi) or unpredictable (e.g., Gullholmen) situations, women do not marry earlier; social constraints (e.g., Goody 1983) or ecological factors (e.g., Low 1990d) seem likely. A complex of strategies is evident (Table 1, Fig. 2): in Locknevi marriage is early, but fertility is delayed; in Gullholmen, mar:iage is delayed.

Although marringe age does not determine reproductive value, which derives from age-specific fertility and mortality patterns $\left(l_{x} m_{x}\right.$ in life tables), marriage patterns certainly can influence reproductive value. In societies like nineteenth century Sweden, in which marriage tends to be very late, the peak of reproductive value can be delayed. Age-specific fertility and mortality are not closely linked to marriage patterns in this sample (Fig. 2; also Low 1989b, 1990b; Low and Clarke 1991a).

The percent of childless marriages increased sharply for women married after age 35 (Fig. 4). However, it is of interest that childhood survivorship for children born to very young and older mothers results in a somewhat different pattern for the percent of marriages resulting in no children surviving to age ten (Fig. 4); survivorship is lower among children born to mothers less than 20 years old, and relatively better for children born to mothers over age 35 . Thus women who married earlier, while they produced more children in their lives, tended to have lower survivorship rates of their children than women who married later $(\mathrm{n}=564, \mathrm{~F}=2.8, \mathrm{p}=0.09)$; the principal difference arose from lower survivorship of children born to women aged 20 or younger (Fig. 4). In light of the late age at marriage in nineteenth century Sweden, this correlation is of interest.

FIGURE 4. The percent of marriages, by woman's age at marriage, which failed to produce children (percent no NBC), or which have no children alive at age 10 (percent, no $\mathrm{RS}_{10}$ ). See text for further discussion.

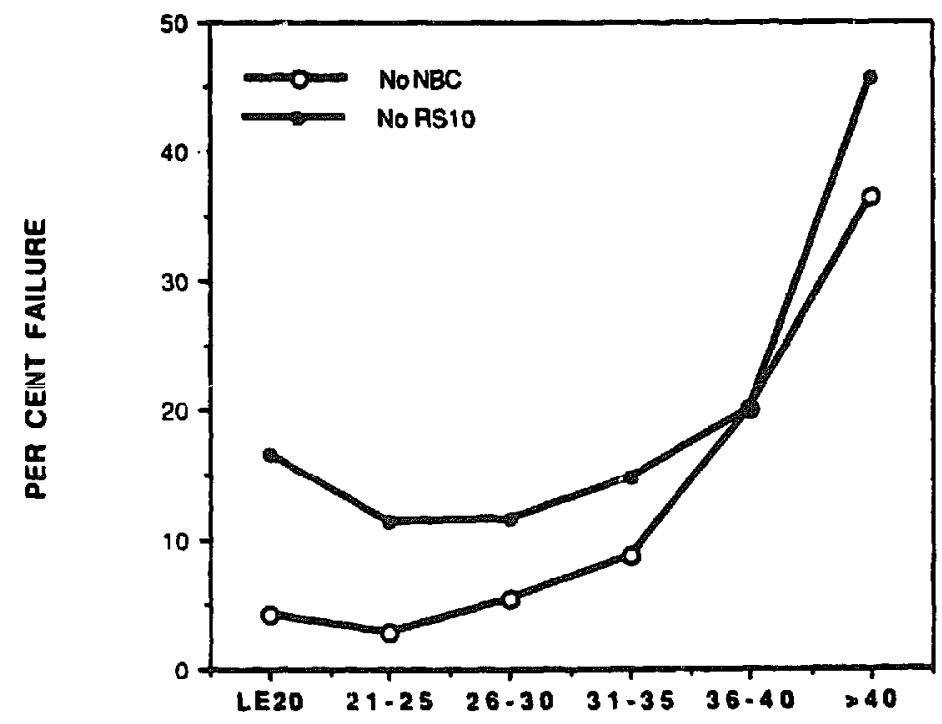


Women tended to have their first child shortly after marriage. For women whose first child was born within marriage, the average interval between marriage and birth was $1.67 \pm 1.86$ years; that is, conception occurred in the first nine months. However, this pattern showed considerable variance (e.g., Locknevi; Fig. 2; Low 1989b; Low and Clarke 1991a).

Women with average inter-birth intervals less than two years, as expected, tended to have more children than women with longer inter-birth intervals (NBC: $n=566, \mathrm{KW}=133.3$, d.f. $=1, \mathrm{p}<0.00001 ; \mathrm{RS}_{10}: \mathrm{n}=$ $566, \mathrm{KW}=36.8$, d.f. $=1, \mathrm{p}<0.001$ ). Short inter-birth intervals, however, may have had impact on the survivorship of children. Children born two years or less apart tended to survive less well (57\% surviving to age ten) than those born two or more years apart $\left(61 \% ; n=3192\right.$, d.î. $=1, X^{2}=$ 5.6. $\mathrm{p}<0.04$ ).

Illegitimacy had important impacts for the mothers of illegitimate children. Women whose first child was illegitimate married for the first time later than other women: 33.2 years versus 24.2 years $(n=1696, t=17.1$, $p<0.00001$ ), and had fewer children in their lives (4.9 versus $6.6 ; n=1696$, $\mathrm{t}=4.4, \mathrm{p}<0.00001$ ).

\section{Women's Versus ỉen's Reproductive Patterns}

Some major reproductive patterns (average number of children, within-fam-

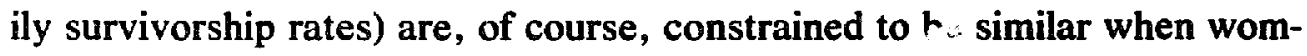
en's and men's lives are compared. Others, like the age of marriage, variance in reproductive success, and the rate and impact of remarriage, are not. The age of marriage for men was greater than that for women (Prediction 1(a)).

Women's age at marriage varied less than men's; this may also be related to the concept of reproductive value. While women's age at marriage varied among parishes, and was not tightly linked to age-specific fertility (Fig. 2, Table 1; also Low and Clarke 1991a), marriages appeared to be constrained by the peak of reproductive value: only four percent of women's first marriages occurred after the peak of reproductive value (Fig. 2(b)). That is, if a woman did not marry by the age of peak reproductive value (remarkably consistent among parishes despite variation in several important patterns; Low and Clarke 1991a), she was unlikely to marry. This correlation between age at marriage might appear to be simpiy an artifact of late age at marriage; there is only $2 \%-7 \%$ illegitimacy, so perhaps reproductive value simply does not rise until most women are married. Yet the large proportiun of women never marrying, the remarriage patterns of widows versus widcwers, and patterns in other societies (even in societies in which women marry very early, well before reproductive value peaks, a woman who does not marry by peak reproductive value has little chance ever to marry), all suggest a more general pattern. Similarly, Kenrick and Keefe (in press) found that preferences ior a mate's age varied with life-history stage, related to reproductive and resource value. 
Widows commonly remarry far less frequently than widowers (Prediction 1(c)), with no obvious demographic or economic explanation. Three hundred and seventy-ithree men (26\%) lost their wives; 131 of these (35\%) remarried. One hundred and forty-two women (19\%) were widowed; thirtyone of these women (22\%) remarried. Others (e.g., Knodel 1981; Knodel and Lynch 1985) have found similar patterns, but found them puzzling, for women's economic value, like men's, does not decline with age-however, women's reproductive value (RV) does decline, and the decline after peak $R V$ is a certainty (declining fecundability), rather than the risk of death which causes lower-than-peak RV at early ages. Women remarried at earlier ages than men $\left(\overline{\mathrm{x}}_{\text {female }}=36.3 \pm 1.91\right.$ years versus $\overline{\mathrm{x}}_{\text {male }}=40.7 \pm 1.13$ years $)$, and women's probability of remarriage declined with age (see also Glick and Lin 1986; Hill and Low in press). This pattern appears to be rather general. In many societies, though the pattern can be slightly modified by the operant sex ratio (Imhof 1981), a strong pattern exists: widows commonly remarry far less frequently than widowers (e.g., Bideau 1980; Wolf 1981; Åkerman 1981; Cabourdin 1981; Imhof 1981; Corsini 1981; Bideau and Perrenoud 1981); widows with dependent children remarry at an even lower rate (e.g., Griffith 1980; Bideau 1980; Corsini 1981; Bideau and Perrenoud 1981); and widows commonly do not remarry at all when they are older (e.g., Cabourdin 1981). In contemporary society, also, these patterns persist (Glick and Lin 1986; Hill and Low in press).

For men, but not women, remarriage had important impacts on fertility (Prediction 1(e)). For the 131 men who married two or more times, the average number of children born in the first marriage was 3.0 (range 0-10), and the average number born in second and subsequent marriages was 2.9 $(0-12)$. Men who remarried thus had significantiy more childre 1 (NBC: $n$ $=1369, \mathrm{KW}=32.2, \mathrm{p}<0.00001)$ and children surviving to age ten $\left(\mathrm{RS}_{10}\right.$ : $\mathrm{n}=1369, \mathrm{KW}=16.7, \mathrm{p}<0.00001)$ than men who married only once. Of the 31 women who remarried, the average number of children born in their first marriage was 3.6 (range 0-9); the average number of children born in second marriages was $1.1(0-4)$. The number of times a woman married was unrelated either to her children born (NBC: $\mathrm{n}=678, \mathrm{KW}=1.97, \mathrm{p}=0.16$ ) or children surviving to age ten $\left(\mathrm{RS}_{10}: \mathrm{n}=678, \mathrm{KW}=0.17, \mathrm{p}=0.68\right)$.

Forty-four percent of second marriages were childless for women, while only twenty-one percent of second and subsequent marriages were childless for men. Thus, women lost their spouses less frequently than men, but they remarried much less frequently than men, and their second marriages were less fecund. Because of women's declining reproductive value, remarriage had less impact on women's fertility than on men's.

For men, resources were important (above, Low 1989b; 1990b; Low and Clarke 1991a); richer men could marry younger women and remarry more often when their spouses died. For women, age at marriage was the most important determinant of lifetime reproduction, and this showed no 
significant patterns with father's or husband's resources (Low 1989b, 1990b; Low and Clarke 1991a), because of death and remarriage patterns.

\section{Sex Ratio and Mother's Age}

In many (principally polygynous) species, including humans, male offspring are more expensive to raise than female offspring (Predictions 8, 9; e.g.. Trivers and Willard 1973; Daly and Wilson 1983): they are carried longer in utero, they are larger at birth, they nurse more and more frequently, and they are weaned later. Although many human societies, particularly nationstates, are currently monogamous (at least nominally, if not biologically), there is little doubt that the evolutionary history of humans is that of polygyny, and male children do tend to be carried slightly longer than females, and weigh more at birth. Trivers and Willard (1973) argued that in polygynous species under such conditions, females in good nutritional condition should be likelier to bear sons than daughters. Thus, pregnancies following closely upon one another are predicted to be less likely to result in sons (cf. CluttonBrock et al. 1982).

The role of age in this relationship is complex. Any age-based version of the Trivers-Willard argument hinges on the probable decline in mother's physiological condition (resources available to rear a successful offspring) with age. In nonhuman species, and in many preindustrial societies and developing countries, this is appropriate. Whenever the nutritional condition of mothers does not decline with age, a male bias might be found in older mothers (Prediction 9; Williams 1966). In fact, if a female's condition is good, a male bias is predicted to be profitable as a woman nears the end of her reproduction-to invest more heavily, with a greater potential reproductive profit if successful (e.g., Mace 1990 reports male-biased sex ratios for older female gorillas). That is, in polygynous iteroparous species, as a female nears the end of reproduction, the more investment she should put into each reproductive bout-to make sons.

The overall sex ratio of children born to the women in this sample was 4035:3867 (1.04:1), typical of the slight male bias seen at birth in most societies. For births for which the sex of the child and the mother's age were known $(n=1927)$, there is a trend towards older mothers giving birth to sons, and younger mothers giving birth to daughters; interestingly, this reflects almost exactly Williams' (1979: Fig. 1) suggestion of an optimally adaptive schedule for sex ratio with age for humans and other single-birth species. Mothers less than 25 years oil showed a sex ratio in their births of $89: 100$, mothers $25-34$ showed a ratio of $96: 100$, while mothers aged 35 and older showed a birth sex ratio of 120:100. Thus, there is evidence of a sexratio bias towards sons with increasing age, making it unlikely that older mothers were in poorer physiological condition (Prediction 9; Fig. 5).

Voland (1984) examined the effect of father's status on children's survival in a nineteenth century German parish. The overall sex ratio of children 


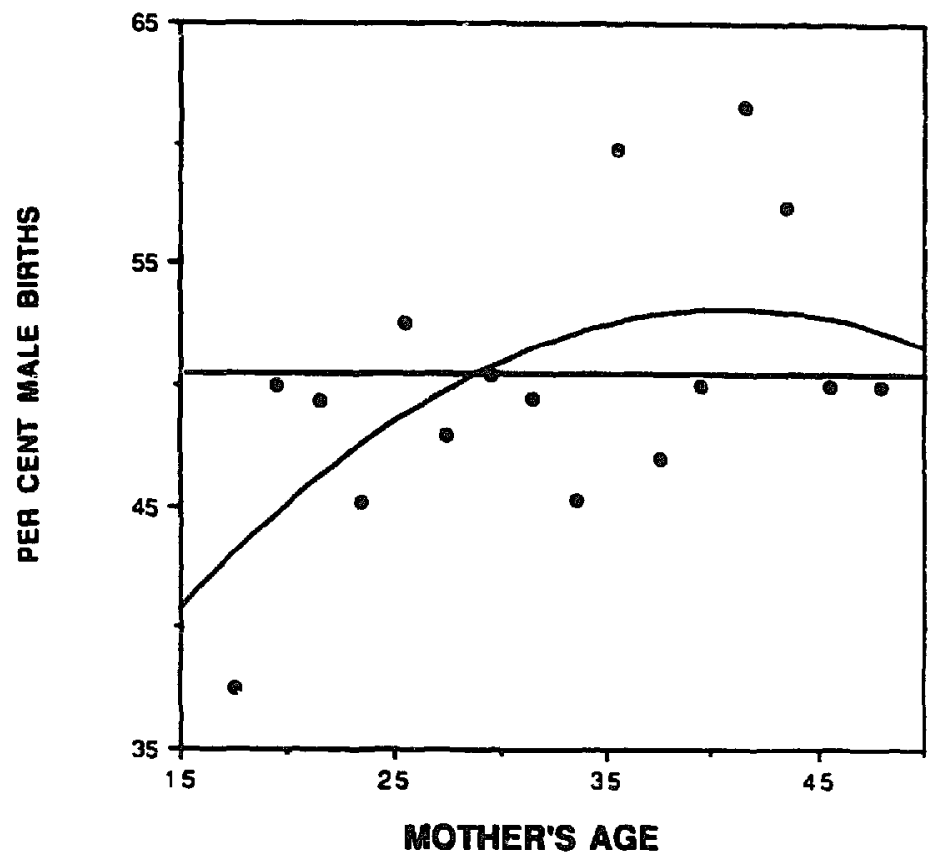

$y=22.308+1.5022 x-1.83110-2 x^{\wedge} 2 \quad R^{\wedge} 2=0.322$

FIGURE 5. As mother's age increased, the proportions of sons born also increased, although not linearly. See text for further explanation.

born was 0.998:1, almost exactly even; the effect of mother's age was not analyzed. Examining deaths during the first year of life due to parental neglect, Voland found status-related patterns. He noted that for farmers, daughters were likely to be considered less desirable than sons (cf. Johansson 1987 , who found "excess female mortality" in aggregate data from Sweden, and attributed it to neglect; but see Low et al. 1991); for other classes, the reverse appeared to be true. First-year mortality followed the predicted patterns. Voland thus has evidence of uneven parental investment tied to the perceived value of each sex for parents in different classes. Abernethy and Yip (1990) found, in contemporary Tennessee, that the survivorship advantage of daughters disappearid $w / 4 h$ increasing educational level of mothers or parents, and for married versus unmarried mothers; that is, sons in higherstatus families did better than others. Gaulin and Robbins (1991) have found a series of other Trivers-Willard effects in contemporary U.S. society. They examined interbirth interval, birth weight, and proportion of children nursed as they related to income and the presence of an adult male in the household. They found that as income increased, so did inter-birth interval and percent breast-fed-for sons, but not daughters. For all seven of their measures. patterns differed for sons versus daughters-the lines crossed, with daughters getting relatively more from low-investment mothers, and sons getting more from high-investment mothers.

In this sample, daughters survived better than sons during the first and 
subsequent years in Tuna, Gullholmen, and Nedertorneå. In Locknevi (undergoing resource constriction), daughter and son survivorship curves were almost identical (Low et al. 1991), a somewhat anomalous result. Fathers' status made no differences to these curves, so no effect was demonstrable in this sample.

\section{Offspring Sex and Inter-Birth Interval}

In polygynous mammals, not only do male offspring typically cost more to raise than female offspring, but later reproductive success varies more for sons than daughters, and the most successful sons may have an order of magnitude more offspring than the most successful daughters (e.g., LeBoeuf and Reiter 1988, Clutton-Brock et al. 1986). Not only the mother's condition as it varies with age might matter (above), but the differential physiological costs of sons versus daughters might influence inter-birth intervals (Prediction 8).

Most mammals for which these calculations are made are seasonal breeders (e.g., red deer and elephant seals); thus the birth of a son, for example, means a more frequent "miss" in conception the following year. Human females, however, are fertile throughout the year. For humans, it may be important to distinguish between the costs imposed by nursing (which would increase the time after a birth of the costly sex) and the costs during gestation (which, if high, make the conception of the more expensive sex likelier to be delayed, and would increase the time before conception of the costly sex). This interaction, I suspect, makes it more difficult to separate effects: does a son make any conception less likely for a longer period? If so, sons should be followed by longer intervals. Does likelihood of conception of a (costly) son vary with a mother's condition? If the latter, sons should be born after longer intervals. In either case, boy-boy intervals should be longest.

Demographic explanations of variability in inter-birth intervals tend to focus on parental preferences for one sex (e.g., Knodel 1988). For example, if parents are seeking to have a son, it is argued, they will try to conceive again quickly after the birth of a daughter. In this case, the birth interval after sons should be longest, regardless of the sex of the next child.

Considering only inter-birth intervals for which both the focai and previous child lived to be at least one year $(n=1029)$, the average inter-birth interval was long $(34.31 \pm 20.07$ months). The longest inter-birth intervals were boy-boy (Fig. 6 ; ANOVA, F $=4.19, p=0.01$ ). If the previous child was a boy, the intervals to the current child were 32.4 months (girl) or 36.2 months (boy); if the previous child was a girl, the intervals to the current child were 33.9 months (girl) or $\mathbf{3 4 . 1}$ months (boy). The sex of the previous child has no effect, suggesting that differences in intervals do not simply reflect the cost of nursing a previous child $(F=0.063, p=0.40)$. The sex of the current child $(F=2.55, p=0.031)$ and the interaction $(F=2.0 ; p$ 


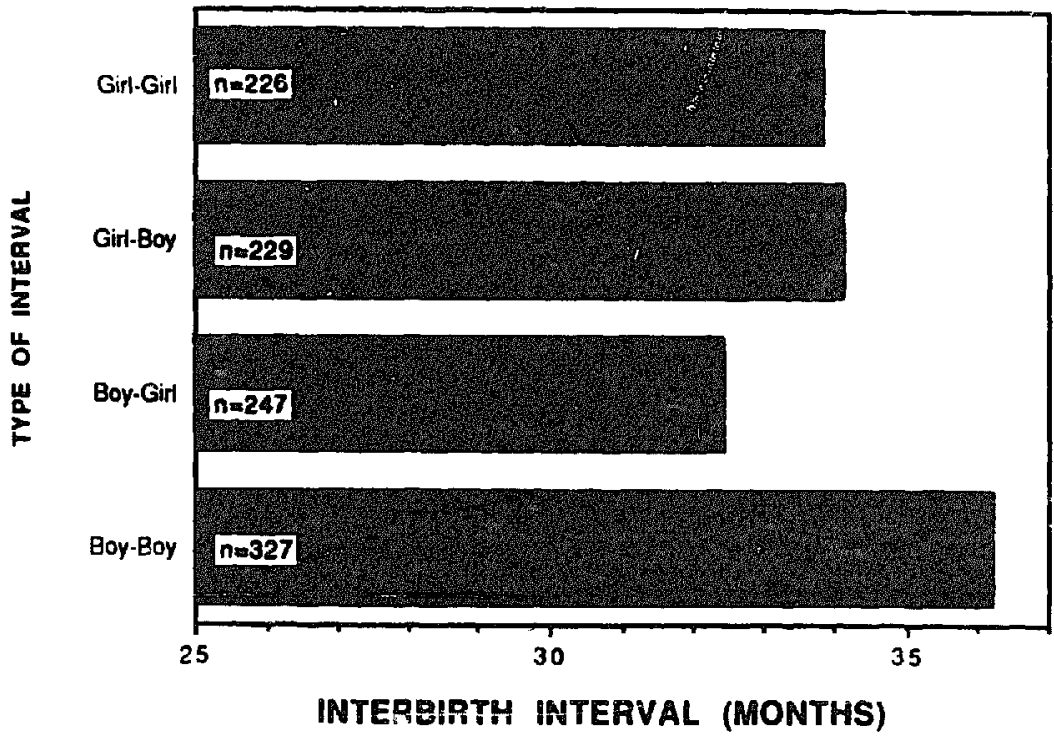

FIGURE 6. Inter-birth interval and sex of children. Boy-boy intervals were significantly longer than all other combinations. Sex of the previous child was unimportant. See text for further discussion.

$=0.016)$ are more important. Thus it does appear that the greater physiological costs of carrying and rearing boys is reflected in inter-birth intervals; it is not, apparently, simply the costs of nursing sons, but it seems possible that the mother's condition may influence the probability of conceiving a son.

\section{Parity, Mother's Age, and Inter-Birth Interval}

Demographers, anthropologists, and biologists are also interested in interbirth intervals as they affect lifetime fertility (e.g., Blurton Jones 1986, 1987 on optimality of birth spacing) and parental choices (e.g., Knodel 1988 on starting, spacing, and stopping behavior). Other things being equal, women who begin reproduction earlier will either have more children (with similar inter-birth intervals) than other women, or will have longer inter-birth intervals (cf. Knodel 1988: 326). The greater a woman's age at the birth of her first child, then, the shorter inter-birth intervals (IBIs) will tend to be for any given lifetime fertility. Given the limits imposed on women's fertility by menopause, the greater the number of confinements, the shorter interbirth intervals will tend to be. As women age and their fecundability declines, IBIs should be longer. The greater the cost of each child to the moti.er (a cost with ecological correlates), and the longer the period over which that cost is extracted (e.g., Turke 1989, 1990; Blurton Jones 1986, 1987, 1989), the longer inter-birth intervals should be. If coital frequency declines with length of marriage or age, this could lengthen the IBI. Finally, if there is any attempt by mothers in pre-contraceptive societies to stop having children 
as they reach "desired" numbers, with some consequent failures, the interbirth interval preceding the last child should be greater than previous intervals (e.g., Knodel 1988: 323). Because several of these factors co-vary, analysis can be difficult, and many analyses do no take mother's age into account.

Inter-birth intervals vary among parishes (means: Locknevi, 36.1 months; Gullholmen, 32.0; Nedertorneå, 27.2; Tuna, 36.5; ANOVA: d.f. = $3,4959 ; \mathrm{F}=80.12 ; \mathrm{p}<0.00001)$. Thus, regressions were run separately for each parish, using the variables: order of child, mother's age, total number of confinements of the mother, whether the child was a last birth or not, and interactions. Although all the regressions had significant slopes, in no case was the total number of confinements or last child-versus-not a significant factor (percent variance explained, other factors held constant, ranged from $0.01 \%$ to $0.5 \%$; $p$ values ranged from 0.26 to 0.96 ). Mother's age at the child's birth is important in all parishes excett Gullholmen (Table 2); in Gullholmen, the age at marriage is late (above) and the sample is small, so little variation in mother's age exists. Birth order of the child and the

Table 2. Factors Affecting Inter-birth Interval.

\begin{tabular}{|c|c|c|c|c|c|}
\hline Parish & Variable & Partial & Coefficient & $t$ & Significance \\
\hline $\begin{array}{l}\text { Locknevi } \\
\mathrm{n}=277 \\
\mathrm{r}^{2}=.34 \\
\mathrm{p}<. .00001\end{array}$ & $\begin{array}{l}\text { constant } \\
\text { child order } \\
\text { (order) }{ }^{2} \\
\text { mother's age } \\
\text { (mother's age) } \\
\text { (order) (age) }\end{array}$ & $\begin{array}{r}0.254 \\
0.299 \\
-0.206 \\
0.313 \\
-0.364\end{array}$ & $\begin{array}{r}105.73 \\
28.05 \\
2.70 \\
-9.10 \\
0.05 \\
-1.62\end{array}$ & $\begin{array}{r}2.94 \\
4.31 \\
5.16 \\
-3.47 \\
5.40 \\
-6.44\end{array}$ & $\begin{array}{c}0.004 \\
<0.00001 \\
<0.00001 \\
0.0006 \\
<0.00001 \\
<0.00001\end{array}$ \\
\hline $\begin{array}{l}\text { Gullhomen } \\
n=158 \\
r^{2}=.31 \\
p<.00001\end{array}$ & $\begin{array}{l}\text { constant } \\
\text { child order } \\
\text { (order) }^{2} \\
\text { mother's age } \\
\text { (mother's age) } \\
\text { (order)'(age) }\end{array}$ & $\begin{array}{r}0.064 \\
0.161 \\
-0.024 \\
0.097 \\
-0.157 \\
\end{array}$ & $\begin{array}{r}12.67 \\
5.08 \\
0.67 \\
-1.05 \\
0.07 \\
-0.42\end{array}$ & $\begin{array}{r}0.244 \\
0.786 \\
2.016 \\
-0.302 \\
1.21 \\
-1.96\end{array}$ & $\begin{array}{l}0.807 \\
0.433 \\
0.046 \\
0.763 \\
0.229 \\
0.052\end{array}$ \\
\hline $\begin{array}{l}\text { Tuna } \\
n=370 \\
r^{2}=.26 \\
p<.00004\end{array}$ & $\begin{array}{l}\text { constant } \\
\text { chi!d a-der } \\
\text { (order) }^{2} \\
\text { mothers' age } \\
\text { 'mother's age) } \\
\text { (order) }(\text { age) }\end{array}$ & $\begin{array}{r}0.154 \\
0.151 \\
-0.160 \\
0.217 \\
-0.177\end{array}$ & $\begin{array}{r}11 ! 23 \\
11.03 \\
0.83 \\
-7.80 \\
0.20 \\
-0.70\end{array}$ & $\begin{array}{r}3.14 \\
2.00 \\
2.91 \\
-3.08 \\
4.24 \\
-3.44\end{array}$ & $\begin{array}{c}0.002 \\
0.047 \\
0.004 \\
0.002 \\
<0.00001 \\
0.0006\end{array}$ \\
\hline $\begin{array}{l}\text { Nedertorneå } \\
\mathrm{n}=540 \\
\mathrm{r}^{2}=.09 \\
\mathrm{p}<.00001\end{array}$ & $\begin{array}{l}\text { constant } \\
\text { child order } \\
\text { (order) }^{2} \\
\text { mother's age } \\
\text { (mother's age) } \\
\text { (order)'(age) }\end{array}$ & $\begin{array}{r}-0.021 \\
0.039 \\
0.080 \\
0.101 \\
-0.024\end{array}$ & $\begin{array}{r}78.18 \\
-1.75 \\
0.14 \\
-3.84 \\
0.08 \\
-0.07\end{array}$ & $\begin{array}{r}2.63 \\
-0.49 \\
0.89 \\
-1.86 \\
0.04 \\
-0.56\end{array}$ & $\begin{array}{l}0.009 \\
0.621 \\
0.374 \\
0.064 \\
0.19 \\
0.579\end{array}$ \\
\hline $\begin{array}{l}\text { Nedertorneå } \\
\text { (excluding infant } \\
\text { mortality) } \\
\mathrm{n}=124 \\
\mathrm{r}^{2}=.23 \\
\mathrm{p}<.00001\end{array}$ & $\begin{array}{l}\text { constant } \\
\text { child order } \\
\text { (order) }^{2} \\
\text { mother's age } \\
\text { (mother's age) } \\
\text { (order)'(age) }\end{array}$ & $\begin{array}{r}0.043 \\
0.110 \\
-0.040 \\
0.110 \\
-0.110\end{array}$ & $\begin{array}{r}31.99 \\
1.37 \\
0.25 \\
-0.59 \\
0.07 \\
-0.24\end{array}$ & $\begin{array}{r}0.69 \\
0.25 \\
1.24 \\
-0.49 \\
1.17 \\
-1.23\end{array}$ & $\begin{array}{l}0.49 \\
0.80 \\
0.22 \\
0.63 \\
025 \\
0.22\end{array}$ \\
\hline
\end{tabular}


interaction of order and mother's age was important in all parishes except Nedertorneå. In Nedertorneå, relationships were quite weak; infant mortality was high, and IBI tended to vary simply with whether the previous child lived or not, swamping other effects. When only cases in which both the previous and current child lived to be at least a year old were considered in Nedertorneå, the explanatory power of the model was improved, although no single factor was relatively so important as in other parishes (Table 2).

Thus, at least in this sample, factors such as total number of mothers' confinements and whether the child was a last child or not, which frequently correlate with length of inter-birth interval, probably do so simply because they co-vary with mother's age.

\section{Number and Sex of Siblings}

The size of a family and the sex of (potentially competitive or dependent) siblings might be expected to influence men's and women's ability to marry at appropriate times somewhat differently (Prediction 7). That is, as shown above and elsewhere (Low 1989b, 1990b), earlier-born sons are likelier to inherit land and other resources, anu men with resources are likelier to raise larger families successfully; brothers may represent a competitive influence for men. On the other hand, birth order does not influence lifetime fertility for daughters, but daughters are more likely than sons to be drawn into caring for siblings at the expense of their own direct reproduction, so that both brothers and sisters may cost a woman reproductively.

Both men's and women's lifetime reproduction (NBC) decreased as their number of siblings increased (Fig. 7). However, the pattern varied for the two sexes. The number of brothers $(n=1683 ;$ d.f. $=1,1,1680 ; \mathrm{F}=$ 14.8; $p=0.009$ ) mattered for men, as did the interaction between number of brothers and number of siblings $(n=1682 ;$ d.f. $=1,1679 ; F=9.4 ; p$ $=0.001)$; the number of siblings $(n=1682 ;$ d.f. $=1,1,1680 ; F=0.24 ; p$ $=0.31$ ) did not. The more brothers in the family, the lower men's lifetime reproduction. For women, the number of siblings $(n=1037$; d.f. $=1,1$, $1034 ; F=3.6 ; p=0.028$ ) was significant, but number of brothers was not ( $\mathrm{n}=1,1 ; 1034 ; \mathrm{F}=0.34 ; \mathrm{p}=0.28$ ).

These data are thus consistent with the possibility that brothers represent resource competitors for men (there is a depressive effect of very large families as well), and that as total sibship size increases for women, they are more likely to be drawn into caring for their siblings (regardless of sex), at some cost to their own reproduction. Although older daughters seem likelier to be affected by having to care for siblings, in this sample, there was no pattern to probability of marrying, or lifetime fertility, with earlierver is later-born daughters in large families. It is unclear why a large number of siblings seems to depress a woman's lifetime reproduction. It would be interesting to examine patterns of dowry; perhaps women with large numbers of siblings, both brothers who get the choice of inheritance, and sisters who 


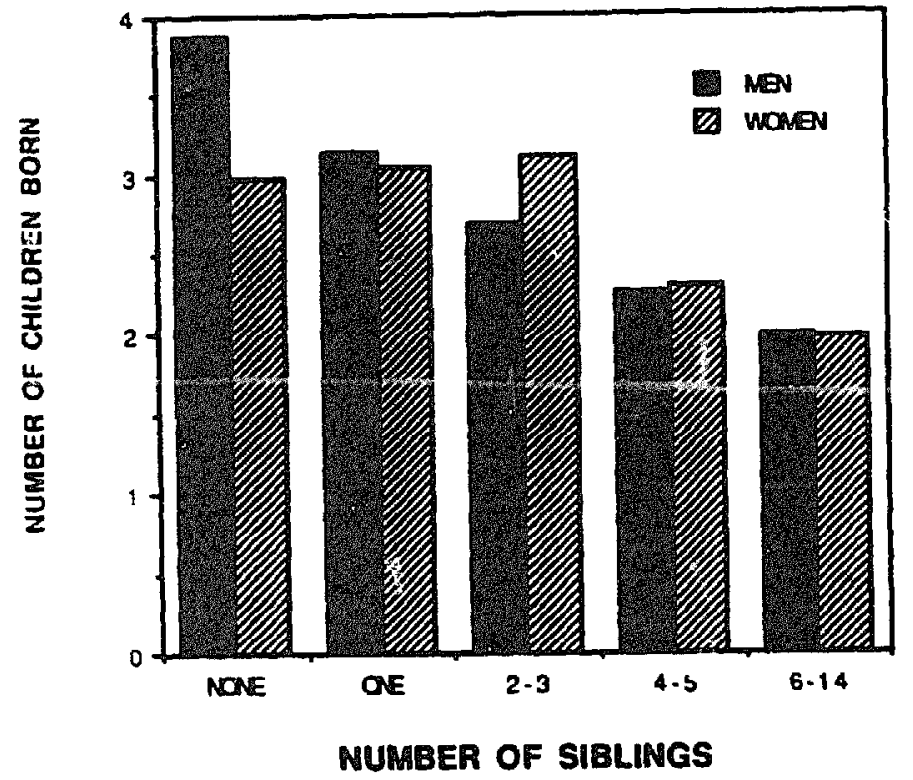

FIGURE 7. The lifetime reproduction (NEC) of both men and women declined as the number of their siblings increased. However (see text), men's reproduction was most sensitive to the number of brothers; while women's reproduction was responsive to the total number of siblings.

compete for dowry portions, get as a result smaller dowries and are less likely to marry. One possible confounding factor is that, for last daughters drawn into caring for their aged parents, when the number of siblings is small, the last daughter may have growr and completed her own reproduction; when the number of siblings is large, mother's age at the birth of the last daughter would be greater, and the daughter younger when pareital care begins-thus youngest daughters with more siblings might show more impact simply because of timing. Insufficient data to solve this exist in this study.

\section{Replacement of Lost Infants?}

Of the four parishes, Nedertornea had both the highest fertility rate (total and age-specific) and the highest infant death rate. Such a correlation suggests that parents might be trying to replace lost infants. Yet such correlations, and the fact that the inter-birth interval is typically shorter after miscarriage or infant death, do not give any clue as to the cause of the correlation.

Individual family data allow another test. If fertility and mortality are not causally related, there should be a relationship between survivorship rate and number of children alive at age ten-but not with familial fertility (Fig. 8(a)). If families are in fact trying to replace lost children, then those families with lower familial rates of survivorship of children to age ten should also show higher fertility; that is, as children die, fertility rises in response (Fig. 8(b); also see Knodel 1988: Table 14.8). Fertility (NBC) is unrelated 


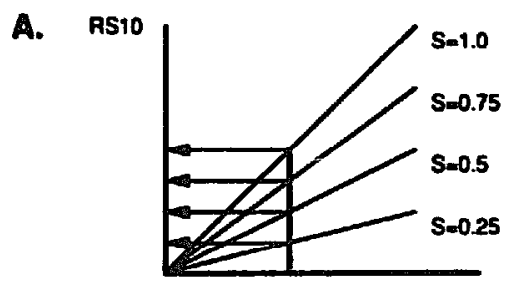

Nac

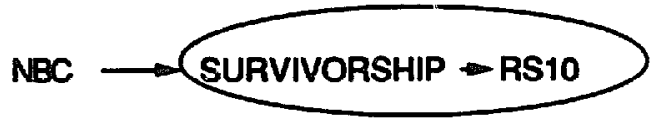

B.

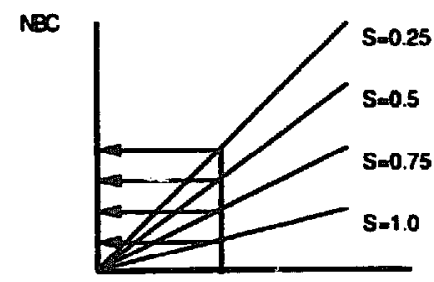

RS10

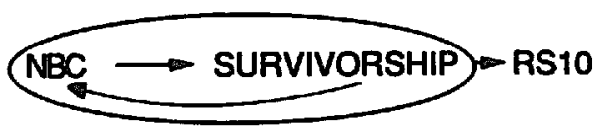

FIGURE 8. (a) If families do not attempt to replace lost children, the number of children alive at age ten will be a simple result of the children born who survive. (b) If replacement occurs, then as survivorship decreases, fertility will increase. That is, at each parity, if a child dies, the number of further children born will increase (cf. Knodel 1988).

to the survivorship rate within families in these data, both in the total sample (regression: $\mathrm{n}=1829, \mathrm{~F}=0.0003, \mathrm{r}^{2}=0.00002, \mathrm{p}=0.99$ ) and in any parish. In contrast, survivorship is strongly related to the number of children aliv : at age ten, suggesting that the causes of mortality are unrelated to the causes of fertility. This information, combined with the fact the inter-birth intervals were shortest in Nedertorneå even when only intervals involving both the focal and previous child living, suggest that in this sample, families were not trying to replace lost infants.

\section{CONCLUSIONS}

The patterns shown by men and women in this sample (as well as many other samples) follow prodictions derived from a behavioral ecological model. Men's and women's reproductive patterns seem linked to resource and reproductive value, respectively (Predictions 1, 2, 3, 4, 5, 6). Women's 
reproduction does not vary with resources, while men's typically does (Low 1989b, 1990b; Low and Clarke 1991a); however, for poorer men, a woman's access to resources appears sometimes to have been of importance, even to the explicit trading of resource for reproductive value. Resource constrictions led to fertility declines and increased out-migration (Prediction 5; Low 1989b; Low and Clarke 1991a, b). Men appeared to be negatively influenced by the number of (potentially competing) brothers (Prediction 7), while women were not. Women married earlier than men, remarried less, and had families in second marriages less often than men. While ages at women's first marriage varied among parishes and was not tightly linked to age-specific fertility, $96 \%$ of women's marriages occurred before the peak of reproductive value (Predictions 1, 2). Physiological costs of producing sons in a mammal with an evolutionary history were reflected in the shifts of inter-birth intervals with sex of offspring (Prediction 8) and the shift in sex ratio with mother's age (Prediction 9). All of these patterns are likely to be culturally influenced, though there need not be conscious consideration of the reproductive effects of any behavior by the individuais involved. It would be of considerable interest to see tests expanded (especially those regarding women's reproductive ecology, in which questions are less welldefined than the tests about men), on societies other than nineteenth-century European ones (e.g., societies in which women's age at marriage is earlier): work swzì as that of Borgerhoff Mulder (1988), Hill and Kaplan (1988a, b), and Hames (1988).

Some patterns predicted and tested for in this paper (e.g., Predictions $2,5,6$, and 8 ) could also be predicted by demographic or economic theory, though for different reasons, and with different predictions about patterns or the efficacy of specific kinds of interventions. This represents convergence from different bodies of theory, working at different levels (proximate versus ultimate costs and benefits). Other patterns predicted here (e.g., Predictions $1,3,4,7$, and 9), are patterns for which demographic and other bodies of theory have not made predictions. In this sample of reproductive behavior in several Swedish populations during the nineteenth century, then, a number of ecologicaily-correlated behaviors are apparent.

Viewed in an evolutionary perspective, many diverse patterns of fertility, of starting, stopping, and spacing children, may become understandable not as non-optimum-because-not-maximum fertility patterns, but as well-tuned adaptive responses to environmental conditions that vary among societies and across time. For example, Blurton Jones' $(1986,1987,1989)$ work suggests that maternal strategies are well-tuned and responsive to the constraint that investment in one child may come at the expense of a mother's ability to invest in other children. Closely spaced pregnancies, when nutrition or other factors are limiting, may result in lowered lifetime fertility, compared to pregnancies spread more distantly in time. !Kung women have inter-birth intervals of about four years (Blurton Jones and Sibley 1978), which at first glance seems far less than possible. But!Kung women may 
depend on bush foods, which means that in their harsh environment they mist walk far carrying their child on their back. Because predators are prevalent, !Kung women may carry their children at least occasionally for up to six years. Blurton Jones $(1986,1987)$ found that, using a model of "backload" (weight of child plus foraged materiai), he could predict quite accurately inter-birth intervals and mortality patterns for bush-living !Kung women. Ten specific predictions were substantiated. !Kung women living in compounds, not dependent on bush foods, showed quite different schedules of births. Thus, the number of successful descendants was enhanced by !Kung women living in the bush not by maximizing births, but by responding to the interaction of production of a new child versus the cost of such production on the survivorship of other children (see also review by Borgerhoff Mulder 1991).

The patterns seen in this analysis also are consistent with a cost-benefit approach, if one uses reproductive as well as economic currencies. Some economic approaches to demographic problems (e.g., Caldwell 1976, 1982, 1983; Handwerker 1986a, b) argue that children can be a net, proximate economic gain for parents in pre-industrial and pre-demographic transition societies. So far, all analyses of actual data suggest that the real situation is considerably more complex (see Turke 1989), but that children's labor is never sufficient to result in a net caloric gain to parents (e.g., Blurton Jones 1986, 1987, 1989; Turke 1985, 1988; Hawkes et al. 1987; Kaplan personal communication). Parents provide for their children, even in societies in which children provide some work. Even grandparents provide for their grandchildren (e.g., Turke 1985; Turke and Betzig 1985; Turke 1988; Kaplan personal communication). Kin do help each other, and kin-helping tends to be preferential according to degree of relatedness, as Hamilton (1964) predicted (e.g., Hames 1988; Flinn 1989; Hawkes et al. 1987; Betzig 1988).

Both economic and Darwinian approaches to fertility in response to costs and benefits recognize that social and economic success are important goals affecting reproductive decisions. But those who do not specify such goals as proximate goals that have, over evolutionary time, correlated with enhanced reproductive success, can make quite different predictions from Darwinians: for example, that it is most rational to produce maximal number of children in traditional societies (e.g., Handwerker 1986a). An evolutionary approach argues that fertility schedules should respond to ecological conditions (e.g., Blurton Jones 1986, 1987, 1989).

Both because of the divergence of predictions from evolutionary versus demographic theory, and because of new predictions, it seems useful to continue exploring, from an evolutionary perspective, individual and familial patterns that give rise to population phenomena.

This work was funded by the American Philosophical Society, the American Scandinavian Foundation, MacArthur Foundation grants to the Population-Environment Dynamics Group, and by internal University of Michigan funds designated by Provost Billy E. Frye. Discussions 
with Bob Smuts, John Rogers, Ken Lockridge, and Jan Sundin were helpful in early stages. Ken Lockridge was extremely generous with his time and experience with similar historical data. The Swedish Demographic Data Base, particularly Gun Stenflo and Anders Brändström, provided extremely competent and supportive assistance in retrieving and converting data to a useable form. Dr. R. Ostergren, University of Wisconsin, graciously shared the mantalslängd information he collected for another analysis. Tom Ten Have, Rob Kushler, Regina Baker, and John Warner were most helpful and patient in statistical consultation. Various drafts were read and given valuable criticism by Paul Turke, Henry Harpending, Kenneth Lockridge, Virginia Vitzthum, Steven Gaulin, John Knodel, John Rogers, Beverly Strassman, and the members of the Evolution and Human Behavior Program of the University of Michigan.

REFERENCES

Abernethy, $Y$., and Yip, R. Parent characteristics and sex differential infant mortality: The case in Tennessee. Human Biology 62(2): 279-290, 1990.

Alexander, R.D., and Sherman, P.W. Local mate competition and parental investment in social insects. Science 196: 494-500, 1977.

Bateson, P. Behavioural development and evolutionary processes. In Current Problems in Sociobiology, King's College Sociobiology Group (Eds.). Cambridge: Cambridge University Press, 1982, pp. 133-151.

Betzig, L.L. Despotism and Differential Reproduction: A Darwinian View of History. Chicago: Aldine, 1986.

-. Adoption by rank on Ifaluk. American Anthropologist 90: 111-119, 1988.

Bideau, A. A demographic and social analysis of widowhood and remarriage: The example of the Castellany of Thoissey-en-Dombes, 1570-1840. I. Family History 5(1); 28-43, 1980.

-, and Perrenoud, A. Remariage et fécondité. Contribution à l'étude des mécanismes de récuperation des populations anciennes. In Marriage and Remarriage in Populations of the Past, J. Dupâquier, E. Hélin, P. Laslett, M. Livi-Bacci, and S. Sogner (Eds.). New York: Academic Press, 1981, pp. 547-559.

Blurton Jones, N. Bushman birth spacing: A test for optimal interbirth intervals. Ethology and Sociobiology 7: 9!-105, 1986.

- Bushman birth spacing: Direct tests of some simple predictions. Ethology and Sociobiology 8: 183-203, 1987.

- The costs of children and the adaptive scheduling of births: Towards a sociobiological Jerspective on demography. In Sexual and Reproductive Strategies, A. Rasa, C. Vogel, and E. Voland (Eds.). Kent: Croom Helm, 1989.

—, and Sibley, R.M. Testing adaptiveness of culturally determined behavior: Do Bushman women maximize their reproductive success by spacing births widely and foraging seldom? S.S.H.B. Symposium 18: Human behavior and adaptation. London: Taylor and Francis, 1978.

Boone, J.L. III. Parental investment and elite family structure in preindustrial states: A case study of late medieval-early modern Portuguese genalogies. American Anthropologist 88: 859-878, 1986.

Borgerhoff Mulder, M. Kipsigis bridewealth payments. In Human Reproductive Behavior: $A$ Danwinian Perspective, L. Betzig, M. Borgerhoff Mulder, and P. Turke (Eds.). Cambridge: Cambridge University Press, 1988, pp. 65-82.

- Kipsigis women's preference for wealthy men: Evidence for female choice in mammals? Behavioral Ecology and Sociobiology 27: 255-264, 1990.

-. Human behavioural ecology. In Behavioral Ecology, J. Krebs and N.B. Davies (Eds.). London: Blackwell, 1991, Chapter 3.

Brändström, A. De Kärlekslösa Mödrarna: Spädbarnsdödligheten i Sverige Under 1800-talet Med Särskild Hänsyn till Nedertorneå. Stockholm: Almqvist \& Wilssell International, 1984.

Cabourdin, G. Le remarriage en France sous l'ancien régime (seizième-dix-huitième siècles). 
In Marriage and Remarriage in Populations of the Past, J. Dupâquie., E. Hélin, P. Laslett, M. Livi-Bacci, and S. Sogner, (Eds.). New York: Academic Press, 1981. pp. 273-285.

Caldwell, J.C. Toward a restatement of demographic transition theory. Population and Development Review 2: 321-366, 1976.

Theory of Fertility Decline. New York: Academic Press, 1982.

- Direct economic costs and benefits of children. In Determinants of Fertility in Deveioping Countries, 2 Vols., R.A. Bulatao and R.D. Lee (Eds.). New York: Academic Press, 1993, p. 458-493, Vol. 1.

Chagnon, N. Sociodemographic attributes of nepotism in tribal populations: Man the rule breaker. In Current Probiems in Sociobiology, King's College Sociobiology Group (Eds.). London: Cambridge University Press, 1982, pp. 291-318.

- Life histories, blood revenge, and warfare in a tribal population. Science 239: 985-992, 1988.

Clarke, A. L., and Low, B.S. Ecological correlates of human migration in 19 th century Sweden. Animal Behavior, in press.

Clutton-Brock, T.H., Guinness, F.E., and Albon, S.D. Red Deer: Behavior and Ecology of Two Sexes. Chicago: University of Chicago Press, 1982.

- Albon, S.D., and Guinness, F.E. Great expectations: Maternal dominance, sex ratios, and offspring reproductive success in red deer. Animal Behavior 34: 460-471, 1986.

Conover, W.J. Practical Non-Parametric Statistics, 2nd Ed, New York: Wiley, 1980.

Corsini, C.A. Why is remarriage a male affair? Some evidence from Tuscan villages during the eighteenth century. In Marriage and Remuriage in Populations of the Past, J. Dupâquier, E. Hélin, P. Lasiett, M. Livi-Baccı, and S. Sugner (Zds.). New York: Academic Press, :981, pp. 385-395.

Daly, M., and Wilson, M. Sex, Evolution, and Behavior, 2nd Ed., Boston: Willard Grant, 1983.

Demographic Data Base. History on Data, Umeå, Sweden: Swedish Demographic Database, Umeå University, 1986.

Drake, M. Population and Society in Norway: 1735-1865, Cambridge: Cambridge University Press, 1969.

Easterli., R.A., Alter, G., and Condran, G.A. Farms and farm families in new and old areas: The northern states in 1860. In Family and Population in Nineteenth-Century America, T.K. Haraven and M.K. Vinovskis (Eds.). Princeton: Princeton University Press, 1978.

Eriksson, I., and Rogers, J. Rural Labor and Population Change: Social anci Demographic Deve!cpment in East-Central Sweden During the Nineteenth Contus, Studia Hietrorica Uppsaliensa 100, 1978.

Essock-Vitale, S.M. The reproductive success of wealthy Americans. Ethology and Sociobiology 5: 45-49, 1984.

Fisher, R... The Genetical Theory of Natural Selection, 2nd Rev. Ed., New York: Dover, 1958.

Flandrin, J.-I . Families in Former Times: Kinship, Household, and Sexuality, translated by Richard Southern. Cambridge: Cambridge University Press, 1979.

Flinn, M. Household composition and reproductive strategies. In Sexual and Reproductive Strategies, A. Rasa, C. Vogel, and E. Voland (Eds.). Kent: Croom Helm, 1989.

Gaulin, S.J.C., and Robbins, C.J. Trivers-Willard effect in contemporary North American society. American Journal of Physical Anthropology 85: 61-68, 1991.

Gaunt, D. I slottets Skuga. Om frälse-bönders sociala problem i Borgeby och Löddekoppinge under 1700-talet. Ale: 15-30, 1977.

- The property and kin relations of retired farmers. In Family Forms in Historic Europe, R. Wall, J. Robin, and P. Lasslett (Eds.). Cambridge: Cambridge University Press, 1983.

- Rural household organization and iniszritance in northern Europe. Journal of Family History 12: 121-141, 1987.

Gerger, T., and Hoppe, G. Education and society: The geographer's view. Acta Universitatis Stockhoimensis 1: 1-124, 1980.

Glick, P. C., and Lin, S.-L. Recent changes in divorce and remarriage. Journal of Marriage and the Family 48: 737-747, 1986. 
Goody, J. The Development of the Family and Marriage in Europe, Cambridge: Cambridge University Press, 1983.

Griff, h, J.D. Economy, family, and remerriage. Theory of remarriage and application to preindustrial England. Journal of Fannily Issues 1(4): 479-496, 1980.

Habbakkuk, H.J. Fam.ly structure and economic change in nineteenth-century Europe. Journal of Economic History 15: 1-12, 1955.

Haines, M.R. Inequality and childhood mortality: A comparison of England and Wales, 1911, and the United States, 1900. Journal of Economic History 45: 885-912, 1985.

Hames, R.H. The allocation of parental care among the Ye'kwana. In Human Reproductive Behavior: A Darwinian Perspective, L. Betzig, M. Borgerhoff Mulder, and P. Turke (Eds.). Cambridge: Cambridge University Press, 1988.

Hamilton, W.D. The genetical evolution of social behaviour I, II. Journal of Theoretical Biology 7: 1-52, 1964.

Hammel, E.A., Johansson, S., and Gunsberg. The value of children during industrialization: Sex ratios in childhood in nineteenth-century America. J. Family History 346-366, Winter 1983.

Handwerker, W.P. The modern demographic transition: An analysis of subsistence choices and reproductive consequences. American Anthropologist 23: 1-12, 1986a.

- Culture and reproduction: Exploring micro/macro linkages. In Culture and Reproduction: An Anthropological Critique of Demographic Transition Theory, W.P. Handwerker (Ed.). Boulder: Westview Press, 1986b.

Hartung, J. Polygyny and the inheritance of wealth. Current Anthropology 5: 77-95, 1982.

Hawkes, K., and Charnov, E.L. Human fertility: Individual or group benefit? Current Anthropology 20: 469-471, 1988.

- , Kaplan, $\mathrm{H}$., and Hill, $\mathrm{K}$. Ache at the settlement: Contrasts between farming and foraging. Human Ecology 15: 133-161, 1987.

Hill, E.M., and Low, B.S. Contemporary abortion patterns: A life-history approach. Ethology and Sociobiology, in press.

Hill, J. Frestige and reproductive success in man. Ethology and Sociobiology 5: 77-95, 1984.

Hill, K., and Kaplan, H. Tradeoffs in male and female strategies among the Ache: Part I. In Human Reproductive Behavior: A Darwinian Perspective, L. Betzig, M. Borgerhoff Mulder, and P. Turke (Eds.). Cambridge: Cambridge University Press, 1988a.

- , and - Tradeoffs in male and femaie strategies cainiong the Ache: Part II. In Human Reproductive Behavior: A Darwinian Perspective, L. Betzig, M. Borgerhoff Mulder, and P. Turke (Eds.). Cambridge: Cambridge University Press, 1988t.

Hughes, A. Reproductive success and occupational class in eighteenth-century Lancashire, England. Social Biology 33: 109-115, 1986.

Imhof, A.E. Remarriage in rural populations and in urban middle and upper strata in Germany from the sixteenth to the twentieth century. In Marriage and Remarriage in Populations of the Past, J. Dupâquier, E. Hélin, P. Laslett, M. Livi-Bacci, and S. Sogner (Eds.). New York: Academic Press, 1981, pp. 335-346.

Inger, G. Svensk Rättshistoria, Liber Laromedel, Lund, 1980.

Irons, W. Investment and primary social dyads. In Evolutionary Biology and Human Social Behavior: An Anthropological Perspective, N.A. Chagnon and W. Irons (Eds.). Boston: Duxbury, 1979a.

- Cultural and biological success. In Evolutionary Biology and Human Social Behavior: An Anthropological Perspective, N.A. Chagnon and W. Irons (Eds.). Boston: Duxbury, 1979 b.

Iohansson, S.R. Status anxiety and demographic contracticin of privileged populations. Popuiation and Develorment Review 13(3): 439-470, 1987.

Jörberg, Lennert. A History of Prices in Sweden: 1732-1914, Vol. 2, Lund: CWK Gleerup, 1972.

-. Structural change and economic growth in rineteenth-century Sweden. In Sweden's Development from Poverty to Affluence, 1750-1970, Steven Koblik (Ed.). Minneapolis: University Minnesota Press, 1975, pp. 92-135.

Kenrick, D.R., and Keefe, R.C. Age preferences in mates reflect sex differences in reproductive strategies. Behavioral and Brain Sciences, in press.

Keyfitz, N. Applied Mathematical Demography, 2nd Ed. New York: Springer-Verlag, 1985. 
Knodel, J. Remarriage and marital fertility in Germany during the eighteenth and nineteenth centuries: An exploratory analysis based on German village genealogies. In Marriage and Remarriage in Populations of the Past, J. Dupâquier, E. Helin, P. Laslett, M. Livi-Bacci, and S. Sogner (Eds.). New York: Academic Press, 1981.

- Demographic transitions in German villages. In The Decline of Fertility in Europe, A.J. Coale and S.C. Watkins (Eds.). Princeton: Princeton University Press, 1986.

- Demographic Behavior in the Past: German Village Populations in the 18th and 19th Centuries, Cambridge: Cambridge University Press, 1988.

- , and Lynch, K.A. The decline of remamiage: Evidence from German viltage populations in the eighteenth and nineteenth centuries. Journal of Family History 10(1): 34-59, 1985.

Le Boeuf, B., and Reiter, J. Lifetime reproductive success in northern elephant seals. In Reproductive Success: Studies of Individual Variation in Contrasting Breeding Systems, T.H. Clutton-Brock (Ed.). Chicago: University of Chicago Press, 1988.

Lesthaeghe, R., and Wilson, C. Modes of production, secularization, and the pace of the fertility decline in western Europe, 1870-1930. In The Decline of Fertility in Europe, A.J. Coale and S.C. Watkins (Eds.). Princeton: Princeton University Press, 1986.

Lee, R.B. The !Kung San, London: Cambridge University Press, 1979.

Livi-Bacci, M. Social-group forerunners of fertility control in Europe. In The Decline of Fertility in Europe, A.J. Coale and S.C. Watkins (Eds.). Princeton: Princeton University Press, 1986.

Lo-Johannsson, F. Sveriges Rikes Lag: Gillad och Antagen På Riksdagen År. 1734, Faksimilutgåva. Malmõ: Gidlunds, 1981.

Low, B.S. Environmental uncertainty and the parental strategies of marsupials and placentals. American 'aturalist 112: 197-213, 1978.

Measures of polygyny in humans. Current Anthropology 29(1): 189-194, 1988.

- Cross-cultural patterns in the training of children: An evolutionary perspective. Journal of Comparative Psychology 103: 311-315, 1989a.

- Occupational status and reproductive behavior in 19th century Sweden: Locknevi Parish. Social Biology 36: 82-101, 1989b.

- Sex, power, and resources: Male and female strategies of resource acquisition. International Journal of Contemporary Sociology 27: 45-71, 1990a.

-. Occupational status, landownership, and reproductive behavior in 19th century Sweden: Tuna Parish. American Anthropologist 92: 115-126, $1990 \mathrm{~b}$.

- An evolutionary perspective on lethal conflict. In New Thinking $:-\pi$ a New Firia of Security, Harolà Jacobson and William Zimerman IV (Eds.). Ann Arbor: University of Michigan Press, 1990c.

- Marriage systems and pathogen stress in human societies. American Zoologist 30: 325339, $1990 d$.

-, and Clarke, A.L. Family patterns in 19th century Sweden: Impact of occupation and land ownership. Journal of Family History 16(2): 117-138, 1991a.

- Historical perspectives on population and environment: Data from 19th century Sweden. In Population-Environment Dynamics: Ideas and Observations, G. Ness and W. Drake (Eds.). Michigan: University of Michigan Press, $1991 \mathrm{~b}$.

- , and Lockridge, K.A. Family Patterns in Nineteenth-century Sweden: Variation in Time and Space, Swedish Demographic Database Report No. 6, 1991.

Mace, G.M. Birth sex ratio and infant mortality rates in captive western lowland gorillas. Folia Primatologica 55(3-4): 156-165, 1990.

Malmström, A. Successionsratt ȟ, Uppsala: Iustrus Forlag, 1981.

Mendels, F.F. Industrialization and Population Pressure in Eighteenth-Century Flanders, New York: Arno Press, 1981.

Mitterauer, M., and Sieder, R. The European Family: Patriarchy to Partnership from the Middle Ages to the Present, translated from the German by $\mathrm{K}$. Oosterveen and M. Horzinger. Chicago: Chicago University Press, 1982.

Paimore, J.A., and Gardner, R.W. Measuring Mortality, Fertility, and Natural Increase: A Self-Teaching Guide to Elementary Measures, Honolulu: East-West Population Center, 1983, p. 140.

Rogers, J. The study of family planning in pre-industrial societies. In Family Building and 
Family Planning in Pre-Industrial Societies, Essays in Social and Historical Demography. Reports from Family History Group, Department of History, No. 1. Uppsala: University of Uppsala, 1980.

Smith, D.S. Parental power and marriage patterns: An analysis of historical trends in Hingham, Massachusetts. Journal of Marriage and The Family 35: 419-428, 1973.

Smith, M.S., Kish, B.J., and Crawford, C.B. Inheritance of wealth as human kin investment. Ethology and Sociobiology 8(3): 171-182, 1986.

Sundbärg, G. Sweden: Its People and Its Industry, Stockholm: P.A. Nordstedt and Sons, 1904. Sundin, J. Theft and penury in Sweden 1830-1920: A comparative study at the county level. Scandinavian Journal of History 1: 265-292, 1976.

Tilly, C. The historical study of vital processes. In Historical Studies of Changing Fertility, C. Tilly (Ed.). Princeton: Princeton University Press, 1978, pp. 1-55.

Trivers, R., and Willard, D.E. Natural selection of parenial ability to vary the sex ratio. Science 179: 90-92, 1973.

Turke, P. Fertility determinants on Ifaluk and Yap: Tests of economic and Darwinian hypotheses, Northwestern University: Ph.D. Dissertation, 1985.

Helpers at the nest: Childcare networks on Ifaluk. In Human Reproductive Behavior: A Darwinian Perspective, L. Betzig, M. Borgerhoff Mulder, and P. Turke (Eds.). Cambridge: Cambridge University Press, 1988.

- Evolution and the demand for children. Population and Development Review 15: 61-90, 1989.

- Which humans behave adaptively, and why does it matter? Ethology and Sociobiology 11: 305-339. 1990.

and Sociobiology 6: 79-87, 1985.

Üterström, G. Jordbrukets Arbetare Den Svenska Arbetarklassens Historia, 2 Vol., Stockholm, 1957.

Vining, D.R. Social versus reproductive success: The central theoretical problem of human sociobiology. The Behavior and Brain Sciences 9: 167-216, 1986.

Voland, E. Human sex-ratio manipulation: Historical data from a German parish. Journal of Human Evolution 13: 99-107, 1984.

Differential reproductive success within the Krummhörn population (Germany, 18th and 19th centuries). Behavioral Ecology and Sociobiology 26: 65-72, 1990.

- and Engel, C. Female choice in humans: A conditional mate selection strategy of the Krummhörn women (Germany, 1720-1874). Ethology 84: 144-154, 1990.

Williams, G.C. Adaptation and Natural Selection, Princeton: Princeton University Press, 1966.

- The question of adaptive sex ratio in outcrossed vertebrates. Proc. Royal Soc. London 205: 567-580, 1979.

Wolf, A.P. Women, widowhood, and fertility in pre-modern China. In Marriage and Remarriage in Populations of the Past, J. Dupâquier, E. Hélin. P. Laslett, M. Livi-Bacci, and S. Sogner (Eds.). New York: Academic Press, 1981, pp. 139-147.

Woolfenden, G.E., and Fitzpatrick, J.W. The Florida Scrub Jay: Demography of a cooperativebreeding bird. Princeton Monographs, Population Biology 20: 1-406, 1984.

Wrigley, E.A., and Schofield, R.S. The Population History of England, 1541-1871: A Reconstruction. Cambridge, MA: Harvard University Press, 1981.

Akkerman, S. The importance of remarriage in the seventeenth and eighteenth centuries. In Marriage and Remarriage in Populations of the Past, J. Dupâquier, E. Helin, P. Laslett, M. Livi-Bacci, and S. Sogner (Eds.). New York: Academic Press; 1981, pp. 163-175. 